\title{
Cellular unfolded protein response against viruses used in gene therapy
}

\author{
Dwaipayan Sen ${ }^{1}$, Balaji Balakrishnan ${ }^{1}$ and Giridhara R. Jayandharan ${ }^{1,2 *}$ \\ 1 Department of Hematology, Christian Medical College, Vellore, India \\ ${ }^{2}$ Centre for Stem Cell Research, Christian Medical College, Vellore, India
}

\section{Edited by:}

Shiu-Wan Chan, The University of

Manchester, UK

Reviewed by:

Kohji Moriishi, University of

Yamanashi, Japan

Masahiro Fujimuro, Kyoto

Pharmaceutical University, Japan

*Correspondence:

Giridhara R. Jayandharan,

Department of Hematology, Centre

for Stem Cell Research, Christian

Medical College, Ida Scudder Road,

Vellore-632004, Tamil Nadu, India

e-mail: jay@cmcvellore.ac.in
Viruses are excellent vehicles for gene therapy due to their natural ability to infect and deliver the cargo to specific tissues with high efficiency. Although such vectors are usually "gutted" and are replication defective, they are subjected to clearance by the host cells by immune recognition and destruction. Unfolded protein response (UPR) is a naturally evolved cyto-protective signaling pathway which is triggered due to endoplasmic reticulum (ER) stress caused by accumulation of unfolded/misfolded proteins in its lumen. The UPR signaling consists of three signaling pathways, namely PKR-like ER kinase, activating transcription factor 6, and inositol-requiring protein-1. Once activated, UPR triggers the production of ER molecular chaperones and stress response proteins to help reduce the protein load within the ER. This occurs by degradation of the misfolded proteins and ensues in the arrest of protein translation machinery. If the burden of protein load in ER is beyond its processing capacity, UPR can activate pro-apoptotic pathways or autophagy leading to cell death. Viruses are naturally evolved in hijacking the host cellular translation machinery to generate a large amount of proteins. This phenomenon disrupts ER homeostasis and leads to ER stress. Alternatively, in the case of gutted vectors used in gene therapy, the excess load of recombinant vectors administered and encountered by the cell can trigger UPR. Thus, in the context of gene therapy, UPR becomes a major roadblock that can potentially trigger inflammatory responses against the vectors and reduce the efficiency of gene transfer.

\section{Keywords: gene therapy, UPR, ER-stress, ER-homeostasis, viral vectors, chaperones}

\section{INTRODUCTION}

One of the important functions of cellular metabolism is protein folding. Endoplasmic reticulum (ER) is the site where all the proteins (secreted, membrane bound, and organelle targeted proteins) are typically processed and folded in eukaryotes (Kaufman et al., 2002; Naidoo, 2009). This accumulates a very high concentration of proteins in the ER which can lead to coaggregation between proteins and/or polypeptides (Stevens and Argon, 1999). Therefore, the lumen of the ER needs a unique environment that promotes processing of proteins but prevents their aggregation (Anelli and Sitia, 2008; Kim et al., 2008; Hetz et al., 2011; Hetz, 2012). Sometimes, due to a high demand in protein synthesis due to various physiological reasons, the processing capacity of the ER can be challenged (Zhang and Kaufman, 2006; Marcinak and Ron, 2010; Hetz et al., 2011). This results in an imbalance in the ER environment, which is referred to as ER stress (Liu and Howell, 2010; Marcinak and Ron, 2010; Hetz et al., 2011; Iwata and Koizumi, 2012). Altered protein folding leading to ER stress can be induced by various factors such as glucose deprivation, aberrant calcium regulation, viral infection and hypoxia. Normally, cells ensure that proteins are correctly folded using a combination of molecular chaperones namely, the foldases and lectins (Naidoo, 2009). If unfolded or misfolded proteins continue to accumulate, eukaryotes induce the UPR. The basic goal of UPR is to recover the (lost) homeostasis (adaptation), reduce stress within the ER compartment and prevent any cytotoxic effect that might be caused by misfolded proteins via adaptive mechanisms as well as by blocking mRNA translation (Xu et al., 2005; Kim et al., 2008; Ye et al., 2011). During adaptation, the UPR tries to correct folding homeostasis via induction of chaperones that promote protein folding (Meusser et al., 2005; Kim et al., 2008). However, when proper folding cannot be restored, incorrectly folded proteins are targeted to ER Associated Degradation (ERAD) pathways for processing (Kaufman et al., 2002). UPR is also known to trigger several molecules of the innate immunity pathway, most notably mitogen- activated protein kinases, $\mathrm{p} 38$ and nuclear factor- $\kappa \mathrm{B}$ (NF- $\mathrm{KB}$ ) which collectively trigger the UPR induced alarm signal (Ron and Walter, 2007; Kim et al., 2008; Tabas and Ron, 2011) to remove translational block and down-regulate the expression and activity of pro-survival factors such as the B-cell lymphoma 2 (Bcl2) protein. However, if the function of the ER cannot be re-established, UPR eliminates the damaged cells by apoptosis or autophagy (Bernales et al., 2006; Kamimoto et al., 2006; Yorimitsu et al., 2006; Hoyer-Hansen et al., 2007; Kouroku et al., 2007). Apart from such a response against de novo synthesized proteins in a cell, the massive accumulation of exogenous proteins intra-cellularly as in the case of viral infection is also known to contribute to ER stress responsive pathways (Zhang and Wang, 2012). 
For a virus to successfully infect mammalian cells, it has to undergo several aspects in its life-cycle-their attachment to cell surface receptors, endocytosis, intracellular trafficking, polypeptide synthesis and genome replication (Balakrishnan and Jayandharan, 2014). Viruses are naturally evolved to utilize host cell machinery to successfully complete their life cycle and during this process they produce several viral proteins within host cells. As a natural response to these foreign proteins, the cell in turn can activate the UPR and interferon response. Thus, a potential mechanism that can limit viral replication is the UPR. It is not surprising that viruses have also evolved mechanisms to manipulate UPR pathways to facilitate their infection (Zhang and Wang, 2012). This generally involves regulation of stress response proteins and several molecular chaperones to modulate UPR and increase ER folding capacity or by induction of translational attenuation to repress the UPR pathways (Zhang and Wang, 2012). Several viruses like adenovirus (Ad), adeno-associated virus (AAV), dengue virus, cytomegalovirus, respiratory syncytial virus, simian virus-5, Tula virus, rota virus African swine fever virus, herpes simplex virus type 1 (HSV-1), hepatitis C virus, corona virus, influenza virus amongst others have been shown to regulate host cell UPR machinery to promote their infection and persistence in the host (Bitko and Barik, 2001; Netherton et al., 2004; Isler et al., 2005; Paradkar et al., 2011; Pena and Harris, 2011; Zhang and Wang, 2012). For example, rotavirus interrupts the inositol requiring protein-1 (IRE1) and activating transcription factor 6 (ATF6) UPR pathways by translational inhibition through its non-structural protein NSP3 (Trujillo-Alonso et al., 2011). Hepatitis $\mathrm{C}$ virus ( $\mathrm{HCV}$ ) has been shown to suppress the IRE1-XBP1 pathway to promote its expression and persistence in the liver (Tardif et al., 2004). Likewise cytomegalovirus uses the viral protein M50 to downregulate IRE1 leading to suppression of UPR (Stahl et al., 2013). This article reviews the tug of war that is initiated by the cell through its UPR signaling against viruses used in gene therapy and dissects how this information can be helpful to improve gene delivery strategies.

\section{UPR PATHWAYS}

Three branches of the UPR have been characterized, which are mediated by ER-located transmembrane proteins: IRE1, protein kinase RNA-like ER kinase (PERK) and ATF6. The binding immunoglobulin protein (BiP) is the master regulator of the UPR. All the three arms of UPR are held in an inactive state by the binding of the BiP to their N-terminal region of IRE1, PERK and ATF6 proteins. When the cell encounters stress, $\mathrm{BiP}$ is released due to competitive binding of the misfolded proteins and thus leading to activation of UPR signaling (Figure 1) (Xu et al., 2005).

\section{IRE1 PATHWAY}

IRE1, the most evolutionarily conserved branch of UPR (Cox et al., 1993) initiates both the pro-survival and pro-apoptotic components in the presence of misfolded proteins. In mammals two isoforms of IRE1 have been identified, IRE1 $\alpha$ and IRE1 $\beta$; IRE1 $\alpha$ is expressed in a variety of tissues (Tirasophon et al., 1998), whereas IRE1 $\beta$ is primarily found in the intestine and lung (Bertolotti et al., 2001; Martino et al., 2013). Mechanistically, when there is an increase in unfolded or misfolded protein load, the BiP molecule interacts with the N-terminus of IRE1, located in the ER lumen. This sensing leads to dimerization of IRE-1 and activates two distinct signaling arms of the IRE-1 pathway. The early signaling occurs through the cleavage of a 26-nucleotide intron from the XBP1-mRNA (Shen et al., 2001; Yoshida et al., 2001; Lee et al., 2002; Malhotra and Kaufman, 2007) generating a $41 \mathrm{kDa}$ frameshift variant (sXBP1). sXBP1 acts as a potent transcription factor that regulates the expression of several protein degradation related genes (Rao and Bredesen, 2004; Malhotra and Kaufman, 2007). The late signaling sensor of IRE1 is initiated when the cytosolic IRE1 $\alpha$ dimers interact with molecules like the tumor necrosis factor receptor-associated factor 2 (TRAF2) which activates the signal-regulating kinase (ASK1) and further activation of cJUN NH2-terminal kinase (JNK) and p38MAPK (Urano et al., 2000). These proteins in turn trigger a proapoptotic signal through pro-apoptotic molecules such as Bim and caspase-3 leading to cell death.

\section{PERK PATHWAY}

PERK is an ER-localized type I transmembrane protein containing a catalytic kinase domain homologous to other kinases of the eukaryotic translation initiation factor 2 (eIF2) such as general control non-depressible-2 (GCN2), heme-regulated inhibitor (HRI) and protein kinase R (PKR) (Harding et al., 1999). The luminal stress sensor domain of PERK is structurally and functionally homologous with the luminal domain of IRE1 $\alpha$, implicating very similar stress-sensing mechanisms between PERK and IRE1 $\alpha$ (Bertolotti et al., 2000). The PERK branch of UPR transduces both the pro-survival as well as pro-apoptotic signals following the accumulation of unfolded or misfolded proteins in the ER. However, its main function is to modulate translation. During initial stages of ER stress, PERK oligomerizes in the ER membrane and induces autophosphorylation (He, 2006). Activated PERK phosphorylates eIF2 $\alpha$ at S51 (Harding et al., 1999; Raven et al., 2008) leading to global attenuation of translational machinery, thus reducing the trafficking of newly synthesized proteins into the already stressed ER compartment. The accumulated protein load is then cleared off from the ER by ERAD pathway with simultaneous expression of pro-survival genes like activating transcription factor 4 (ATF4) (Harding et al., 2003). ATF4 is not affected by the global eIF2 $\alpha$ translational block because of the presence of internal ribosome entry site (IRES) sequences in the $5^{\prime}$ untranslated regions (Schroder and Kaufman, 2005). However ATF4 can drive the cell toward apoptosis by inducing expression of factors like $\mathrm{C} / \mathrm{EBP}$ homologous protein $(\mathrm{CHOP})$ and growth arrest and DNA damage-inducible protein 34 (GADD34) (Zinszner et al., 1998; Novoa et al., 2003).

\section{ATF6 PATHWAY}

ATF6 is a type II ER transmembrane protein belonging to the bZIP family of transcription factors. The ER luminal domain acts as the sensor for ER stress due to the protein overload while the cytoplasmic domain acts as a transcription factor (49). ATF6 has two homologs- ATF6 $\alpha$ (Hai et al., 1989; Haze et al., 1999) and ATF6 $\beta$ (Min et al., 1995; Khanna and Campbell, 1996; Haze et al., 2001) with redundant roles in UPR. Upon dissociation of BiP from the N-terminus of ATF6 following ER stress, it translocates 


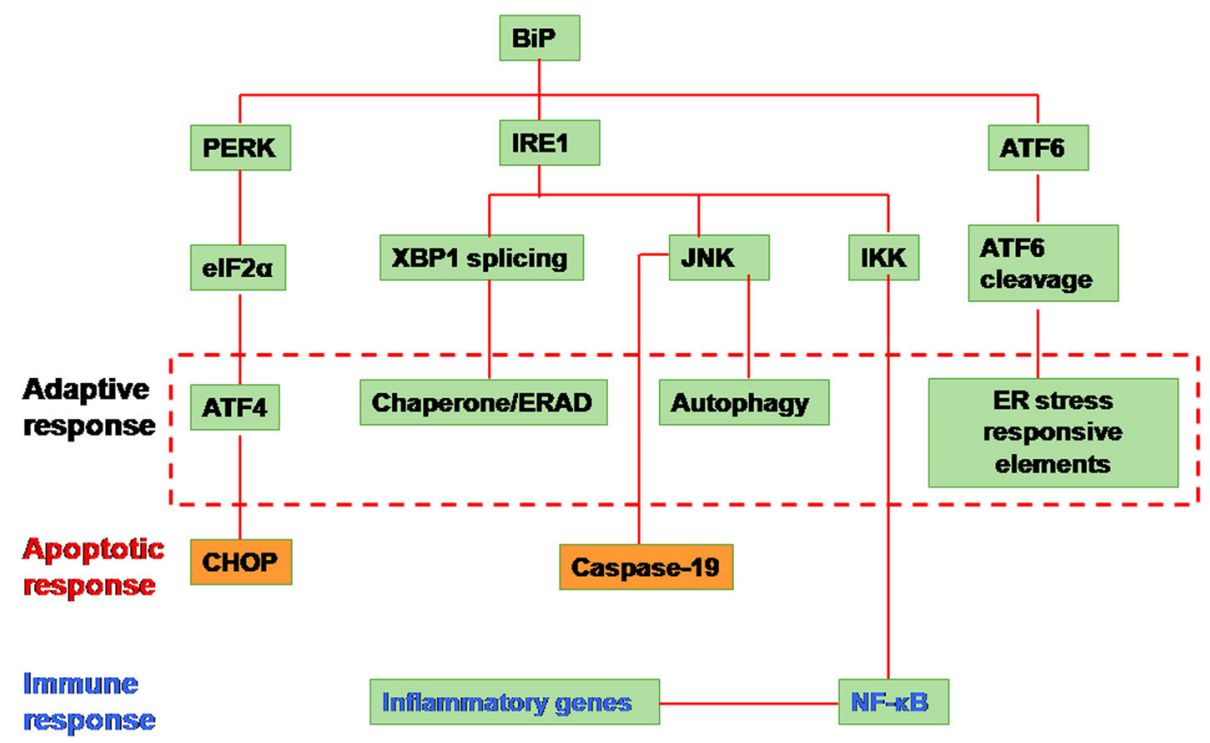

FIGURE 1 | Unfolded protein response signaling. The signaling is initiated by the activation of the proximal sensors of the unfolded protein response (UPR) namely, (1) protein kinase $R$ (PKR)-like ER kinase (PERK), (2) activating transcription factor (ATF) 6 and (3) inositol-requiring enzyme 1 (IRE1). A protein called immunoglobulin heavy chain binding protein (BiP) functions as the master regulator. BiP under normal conditions remains attached to all the three sensors in the luminal domain of the endoplasmic reticulum (ER). Upon encountering any stress like accumulation of misfolded/unfolded proteins or a massive inflow of any exogenous proteins into the ER, the stress sensors, PERK, IRE1, and ATF6, are activated by the release of BiP from the sensors leading to any of the three distinct pathways. (1) When PERK is activated, it dimerises and autophosphorylates leading to phosphorylation of the eukaryotic translation initiation factor (elF) $2 \alpha$. Activated elF2 $\alpha$ represses global protein translation of the cell. However the downstream protein called ATF 4 can escape translational repression since it has upstream open reading frames leading to its activation. The activated ATF4 translocates into the nucleus activating a set of target genes to restore cellular homeostasis (adaptive response). However in situations when the cellular homeostasis cannot be restored, C/EBP homologous protein (CHOP) is activated leading to apoptosis. (2) When IRE1 is activated, it dimerizes and autophosphorylates leading to the activation of its endoribonuclease activity. This leads to an unusual splicing of XBP1 (X-box binding protein 1) cleaving 26 nucleotide intron within. The Spliced XBP1 (sXBP1) protein translocates to nucleus transcribing chaperones and unfolded protein response elements (UPREs) to restore cellular homeostasis. In some cases, the IRE1 activates the cellular JNK through phosphorylation. This activated JNK either leads to apoptosis by activaton of caspase 19 or leads to autophagy. Alternatively, IRE1 activates IKK by interacting with tumor necrosis factor receptor-associated factor 2 (TRAF2) which phosphorylates $I_{\kappa} B$. This releases nuclear factor (NF)-кB. The activated $\mathrm{NF}-\kappa \mathrm{B}$ translocates into the nucleus and transcribes inflammatory genes. (3) Activation of the third sensor of UPR, ATF6 leads to its translocation into the Golgi complex. In the golgi complex, ATF6 will be cleaved by proteases such as site-1 protease (S1P) and S2P. This cleaved ATF6 fragment further transcribes chaperones and UPRE to cope with the cellular stress and restore homeostasis (Yoshida et al., 2001; Lee et al., 2002; Harding et al., 2003; Novoa et al., 2003; Wu et al., 2007; Yamamoto et al., 2007; Raven et al., 2008). from the ER to the golgi where it is cleaved by resident proteases like site 1 protease (S1P) and site protease (S2P) (Hetz et al., 2011) to release its cytoplasmic DNA binding fragment called ATF6f. ATF6 $f$ increases degradation of unfolded proteins as well as induces the activity of several ER chaperone proteins like $\mathrm{BiP}$, protein disulfide isomerase (PDI) and ER degradation-enhancing alpha-mannosidase-like protein 1 (EDEM1) (Wu et al., 2007; Yamamoto et al., 2007).

\section{GENE THERAPY}

In the last two decades, gene therapy has been immensely popular to treat various inherited as well as acquired disorders (Kay, 2011; Misra, 2013). Gene therapy involves either replacing a mutated gene with a healthy copy or introducing a new gene into the cells to help protect against the disease. Despite significant success seen in the treatment of diseases such as lipoprotein lipase deficiency (Gaudet et al., 2012), haemophilia B (Manno et al., 2006; Nathwani et al., 2011), Leber's Congenital Amaurosis (Simonelli et al., 2010) or severe combined immunodeficiency
(SCID) (Cavazzana-Calvo et al., 2000), the safety and efficacy of this novel modality of treatment recognizably needs to be improved. For a clinically relevant gene therapy protocol, the efficient delivery and optimal expression of the gene of interest are very important. Since viruses are naturally evolved to efficiently infect and transfer DNA into the host, engineered (gutted) viruses are the most desirable as gene delivery vehicles. Viral vectors currently available for gene therapy can roughly be categorized into integrating and non-integrating vectors. Vectors based on retroviruses (including lentivirus and foamy virus) have the ability to integrate their viral genome into the chromosomal DNA of the host cell, which can theoretically achieve life-long gene expression. Vectors based on Ad, AAV and HSV-1 represent the non-integrating vectors (Table 1). These vectors deliver their genomes into the nucleus of the target cell, where they continue to remain episomal. Viral vectors derived from retroviruses, Ad, AAV and HSV have been employed in the majority of gene therapy clinical trials (Table 2). Recognizing the activation and basis of cellular events like UPR in response to a virus 
Table 1 | Characteristics of the common viruses used in gene therapy.

\begin{tabular}{|c|c|c|c|c|c|c|c|}
\hline Viral Vector & Description & $\begin{array}{l}\text { Associated } \\
\text { disease }\end{array}$ & $\begin{array}{c}\text { Maximum } \\
\text { transgene } \\
\text { capacity }\end{array}$ & $\begin{array}{l}\text { Host } \\
\text { genome } \\
\text { integration }\end{array}$ & $\begin{array}{l}\text { Transduction of } \\
\text { cells }\end{array}$ & Advantages & Disadvantages \\
\hline Adenovirus & $\begin{array}{l}36 \mathrm{~kb} \text { dsDNA, } \\
\text { non-enveloped, } \\
\text { icosahedric, } \\
70-90 \mathrm{~nm} \text { in } \\
\text { diameter }\end{array}$ & Yes & $\sim 30 \mathrm{~kb}$ & No & $\begin{array}{l}\text { Both dividing and } \\
\text { non-dividing }\end{array}$ & $\begin{array}{l}\text { Easy production of } \\
\text { high titres, ability to } \\
\text { infect a wide range } \\
\text { of cell types, } \\
\text { capacity to carry } \\
\text { large transgene }\end{array}$ & $\begin{array}{l}\text { Adverse host } \\
\text { humoral and cellular } \\
\text { immune response, } \\
\text { transient gene } \\
\text { expression }\end{array}$ \\
\hline $\begin{array}{l}\text { Retroviruses } \\
\text { (retrovirus and } \\
\text { lentivirus) }\end{array}$ & $\begin{array}{l}\text { 7-10 kb ssRNA, } \\
\text { enveloped, } \sim 100 \mathrm{~nm} \\
\text { diameter }\end{array}$ & Yes & $\sim 8 \mathrm{~kb}$ & Yes & $\begin{array}{l}\text { Both dividing and } \\
\text { non-dividing }\end{array}$ & $\begin{array}{l}\text { High infection } \\
\text { efficiency, stable } \\
\text { and permanent } \\
\text { gene transfer }\end{array}$ & $\begin{array}{l}\text { Insertional } \\
\text { mutagenesis causing } \\
\text { cancer, high } \\
\text { immunogenicity }\end{array}$ \\
\hline $\begin{array}{l}\text { Adeno associated } \\
\text { virus (AAV) }\end{array}$ & $\begin{array}{l}4.7 \mathrm{~kb} \text { ssDNA, } \\
\text { Icosahedric, } \\
\text { non-enveloped, } \\
\sim 22 \mathrm{~nm} \text { diameter }\end{array}$ & No & $\sim 4.7 \mathrm{~kb}$ & No & $\begin{array}{l}\text { Both dividing and } \\
\text { non-dividing }\end{array}$ & $\begin{array}{l}\text { Low } \\
\text { immunogenicity, } \\
\text { non-infectious }\end{array}$ & $\begin{array}{l}\text { Limited transgene } \\
\text { carrying capacity, } \\
\text { not suitable to target } \\
\text { rapidly dividing cells }\end{array}$ \\
\hline Herpesvirus-HSV-1 & $\begin{array}{l}\sim 152 \mathrm{~kb} \text { dsDNA, } \\
\text { icosahedric } \\
\text { enveloped, } \sim 125 \mathrm{~nm} \\
\text { diameter }\end{array}$ & Yes & $\sim 150 \mathrm{~kb}$ & No & Only dividing cells & $\begin{array}{l}\text { Large transgene } \\
\text { carrying capacity, } \\
\text { production of high } \\
\text { titres }\end{array}$ & $\begin{array}{l}\text { Host immune } \\
\text { response, short term } \\
\text { gene expression }\end{array}$ \\
\hline
\end{tabular}

used in gene therapy is important to further optimize gene delivery.

\section{HSV AND UPR}

HSV-1 is a large $(\sim 152 \mathrm{~kb})$ fast replicating, enveloped, double stranded (ds) DNA virus. The mature viral particle consists of 3 components- an external envelope made of about 13 glycoproteins which helps the virus to bind and enter the host cell; a second layer called tegument which contains 20 different structural and regulatory proteins and finally an icosohedral capsid containing the genetic material. HSV is an attractive choice as a gene therapy vector for various reasons, including its broad tropism, host range and its cellular receptors (Arii et al., 2009; Fan et al., 2009; Wang et al., 2009b), their ability to infect non-dividing cells with high efficiency, high production titers for recombinant particles and a stable/long-term expression of therapeutic genes especially in neurons (Norgren and Lehman, 1998). Three types of HSV-1 vectors are currently in use in gene therapy- replicationdefective, replication-competent vectors and amplicons. Deleting one or more genes involved in the lytic cycle creates a replicationdefective vector. Replication-competent viruses are attenuated for genes that are not essential for replication in vitro (Hu and Coffin, 2003; Post et al., 2004). The amplicons are derived from engineered plasmids, which contain both the HSV packaging recognition sequence (pac) and the origin of replication (ori). These amplicons can be efficiently packaged in mammalian cells as concatamers with the help of HSV helper elements. Also, amplicons are non-toxic and can carry very large DNA fragments of upto $152 \mathrm{~kb}$ (Epstein, 2009). Both replication defective and replication competent HSV vectors have been used in gene therapy of several neurological disorders (Table 1). Replication defective HSV vectors have been shown to efficiently transduce both dividing and non-dividing cells including tumors. Taking advantage of this property, HSV vector have been engineered to deliver anticancer transgenes into tumour cells such as melanoma (Krisky et al., 1998; Niranjan et al., 2003), gliosarcoma (Moriuchi et al., 2002; Niranjan et al., 2003) or glioblastoma (Niranjan et al., 2000).

One of the major factor that negatively affects HSV mediated gene delivery is the host immune response directed against it, including the innate and adaptive responses (Ryan and Federoff, 2009). As a first line of defense, innate immunity is a major ratelimiting factor in HSV transduction. One of the principal effector underlying anti-HSV innate defense, is the process of autophagy that is initiated through the cellular UPR pathway (Lee et al., 2009).

During replication of HSV, there is a rapid generation of large amount of viral proteins that may induce UPR and consequently necessitate modulation of the cellular stress response (Figure 2A). Indeed, a number of HSV-1 proteins have been shown to block phosphorylation of eIF2 $\alpha$, an important stress response mechanism of the cell, which leads to the attenuation of protein synthesis (He et al., 1996; Cassady et al., 1998; Mulvey et al., 2003, 2006, 2007). Cassady et al. (1998) and Mulvey et al. (2003) showed that a HSV viral protein, US11 can repress two kinases (eIF2 $\alpha$, PKR) and PERK upon HSV infection (Figure 2A) (Cassady et al., 1998; Mulvey et al., 2003). He et al., demonstrated that a late protein $\gamma_{1} 34.5$ can dephosphorylate eIF2 $\alpha$ with the help of the cellular phosphatase PP1 $\alpha$ (He et al., 1996). This inhibition resulted in a 1000-fold increase in the replication efficiency of HSV1 (Talloczy et al., 2006). It has been shown that HSV-1 infection does not activate PERK as well as IRE and was also highly resistant to acute ER stress (Mulvey et al., 2007). 
Table 2 | Viral vectors used in clinical trials (Last date of access-24th March, 2014).

\begin{tabular}{|c|c|c|c|}
\hline Viral vectors & Disease target & $\begin{array}{c}\text { Clinicaltrials.gov } \\
\text { identifier }\end{array}$ & Last update \\
\hline Ade & $\begin{array}{l}\text { Cystic fibrosis } \\
\text { Ovarian cancer } \\
\text { Metastatic breast cancer } \\
\text { Lung cancer } \\
\text { Brain tumor } \\
\text { melanoma } \\
\text { Bladder cancer }\end{array}$ & $\begin{array}{l}\text { NCT00004779 } \\
\text { NCT00964756; } \\
\text { NCT00562003 } \\
\text { NCT00307229; } \\
\text { NCT00197522 } \\
\text { NCT00776295 } \\
\text { NCT00004080 } \\
\text { NCT01397708 } \\
\text { NCT00003167 }\end{array}$ & $\begin{array}{l}\text { June 23, 2005 } \\
\text { February 11, 2013; } \\
\text { January 25, 2011 } \\
\text { May 31, 2012; } \\
\text { October 31, } 2012 \\
\text { January 16, } 2013 \\
\text { February 6, } 2009 \\
\text { March 11, } 2014 \\
\text { January 22, } 2013\end{array}$ \\
\hline Adeno-associated virus (AAV) & $\begin{array}{l}\text { Retinal disease } \\
\text { Pompe disease } \\
\text { Late infantile neuronal ceroid lipofuscinosis } \\
\text { Leber congenital amaurosis } \\
\text { Alpha-1 antitrypsin deficiency } \\
\text { Cystic fibrosis } \\
\text { Idiopathic Parkinson's disease } \\
\text { Hemophilia B } \\
\text { Duchenne muscular dystrophy } \\
\text { Lipoprotein lipase deficiency }\end{array}$ & $\begin{array}{l}\text { NCT01482195 } \\
\text { NCT00976352 } \\
\text { NCT01161576 } \\
\text { NCT00749957; } \\
\text { NCT00643747; } \\
\text { NCT00999609; } \\
\text { NCT00516477 } \\
\text { NCT01054339; } \\
\text { NCT00377416; } \\
\text { NCT00430768 } \\
\text { NCT00004533 } \\
\text { NCT00985517 } \\
\text { NCT01687608; } \\
\text { NCT01620801; } \\
\text { NCT00076557; } \\
\text { NCT00515710; } \\
\text { NCT00979238 } \\
\text { NCT00428935 } \\
\text { NCT01109498; } \\
\text { NCT00891306 }\end{array}$ & $\begin{array}{l}\text { November 29, } 2011 \\
\text { December 13, } 2013 \\
\text { November 5, 2013 } \\
\text { March 6, 2013; } \\
\text { December 13, 2013; } \\
\text { January 13, 2014; } \\
\text { January 13, 2014 } \\
\text { March 6, 2013; } \\
\text { December 20, 2013; } \\
\text { December 20, } 2013 \\
\text { June 23, 2005 } \\
\text { December 10, } 2012 \\
\text { September 19, } 2013 \text {; } \\
\text { December 20, } 2013 \text {; } \\
\text { April 2, 2007; } \\
\text { December 20, } 2013 \text {; } \\
\text { December 20, } 2013 \\
\text { February 4, 2013 } \\
\text { September 29, } 2011 ; \\
\text { September 28, } 2011\end{array}$ \\
\hline Herpes simplex virus vectors & $\begin{array}{l}\text { Melanoma, liver cancer, pancreatic cancer, lung cancer } \\
\text { Refractory non-central nervous system (non-CNS) solid tumors } \\
\text { Head and neck cancer or solid tumors }\end{array}$ & $\begin{array}{l}\text { NCT01935453 } \\
\text { NCT00931931 } \\
\text { NCT01017185 }\end{array}$ & $\begin{array}{l}\text { August 30, } 2013 \\
\text { November 5, } 2013 \\
\text { February 18, } 2013\end{array}$ \\
\hline & $\begin{array}{l}\text { Lymphoma } \\
\text { Acute myeloid leukaemia } \\
\text { ADA-deficient severe combined immunodeficiency (ADA-SCID) } \\
\text { X-linked severe combined immunodeficiency (X-SCID) } \\
\text { Fanconi anaemia } \\
\text { Wiskott-aldrich syndrome } \\
\text { AIDS-related non-hodgkin lymphoma }\end{array}$ & $\begin{array}{l}\text { NCT00569985 } \\
\text { NCT00718250 } \\
\text { NCT01852071 } \\
\text { NCT01306019 } \\
\text { NCT01331018 } \\
\text { NCT01515462 } \\
\text { NCT01961063 }\end{array}$ & $\begin{array}{l}\text { January 6, } 2014 \\
\text { July } 16,2008 \\
\text { January } 14,2014 \\
\text { March } 14,2014 \\
\text { March } 6,2014 \\
\text { January } 18,2012 \\
\text { October } 30,2013\end{array}$ \\
\hline & $\begin{array}{l}\text { Chronic granulomatous disease } \\
\text { CNS tumors } \\
\text { X-Linked severe combined immunodeficiency (X-SCID) } \\
\text { ADA-deficient severe combined immunodeficiency (ADA-SCID) } \\
\text { Leukocyte adherence deficiency } \\
\text { Chronic granulomatous disease (CGD) } \\
\text { Gaucher's disease } \\
\text { Sickle cell anaemia and } \beta \text {-thalassemia } \\
\text { Mild hunter synrome } \\
\text { HIV infection } \\
\text { Gyrate atrophy }\end{array}$ & $\begin{array}{l}\text { NCT00778882 } \\
\text { NCT00005796 } \\
\text { NCT00028236 } \\
\text { NCT00598481; } \\
\text { NCT00599781; } \\
\text { NCT00794508 } \\
\text { NCT00023010 } \\
\text { NCT00564759; } \\
\text { NCT00001476 } \\
\text { NCT00001234 } \\
\text { NCT00669305 } \\
\text { NCT00004454 } \\
\text { NCT00001535 } \\
\text { NCT00001735 }\end{array}$ & $\begin{array}{l}\text { January } 15,2014 \\
\text { October 22, } 2009 \\
\text { July 26, 2011 } \\
\text { December 12, 2013; } \\
\text { January 23, 2008; } \\
\text { February 7, } 2013 \\
\text { December 14, } 2010 \\
\text { November 27, } 2007 ; \\
\text { December 14, } 2010 \\
\text { March 3, 2008 } \\
\text { December 20, } 2013 \\
\text { June 23, 2005 } \\
\text { February 7, } 2008 \\
\text { March 3, 2008 }\end{array}$ \\
\hline
\end{tabular}


This resistance of PERK toward activation by ER stress in HSV-1 infected cells is attributed to the glycoprotein $\mathrm{B}(\mathrm{gB})$ associated with the luminal region of PERK (Figure 2A). This study also showed a genetic association between PERK and $\mathrm{gB}$ which could regulate the viral protein load in infected cells (Mulvey et al., 2007). To further understand how HSV1 modulates cellular UPR, Burnett et al., reported that HSV-1 can deactivate UPR in the early stages of infection (Burnett et al., 2012). The study observed early

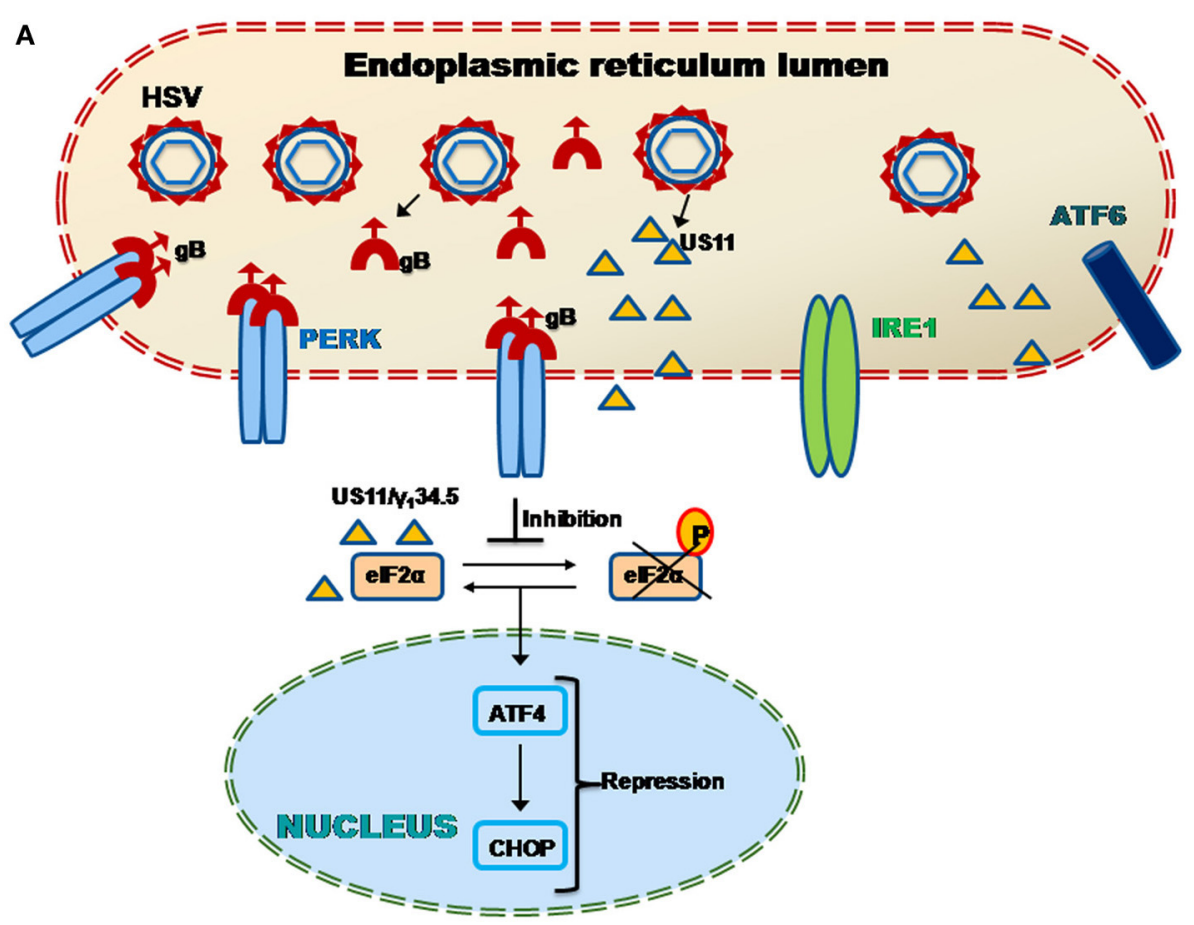

B

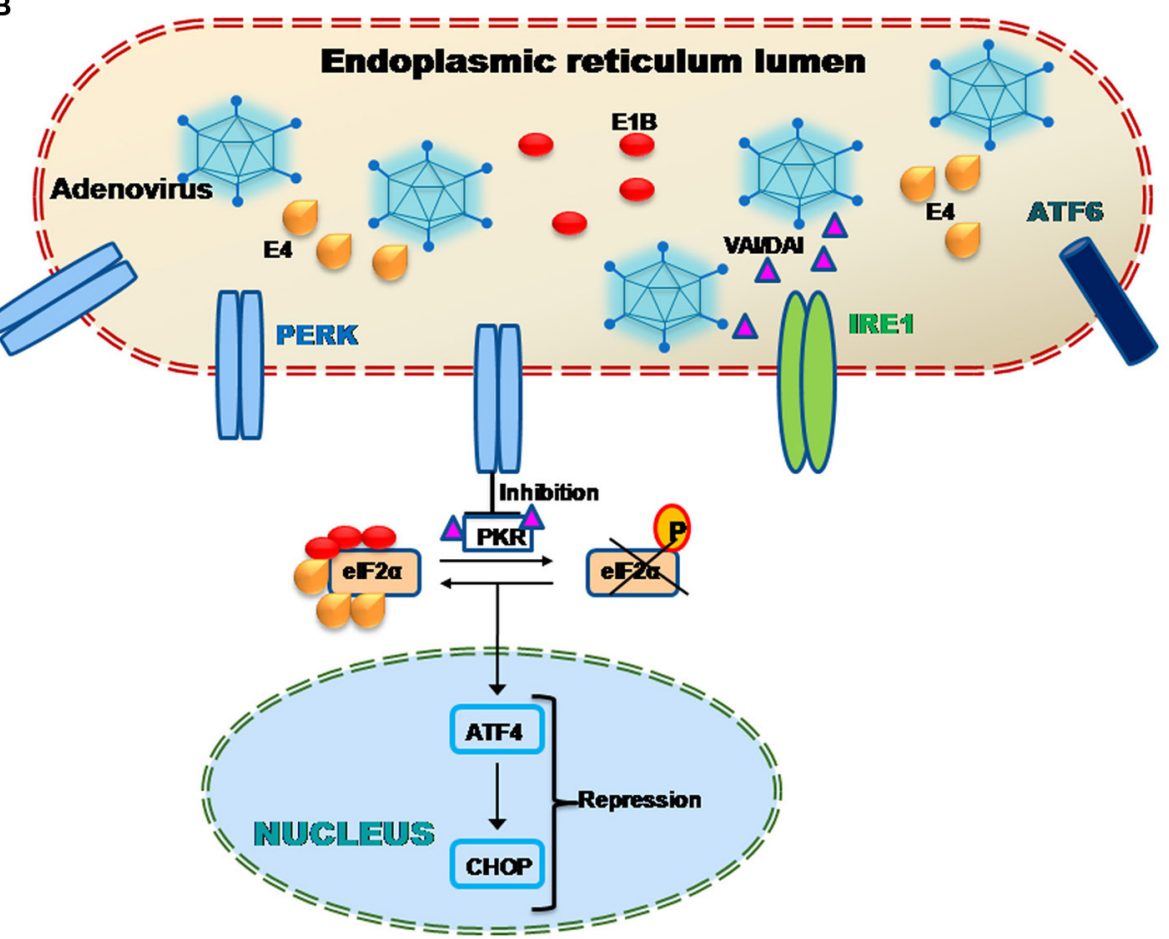

FIGURE 2 | Continued 

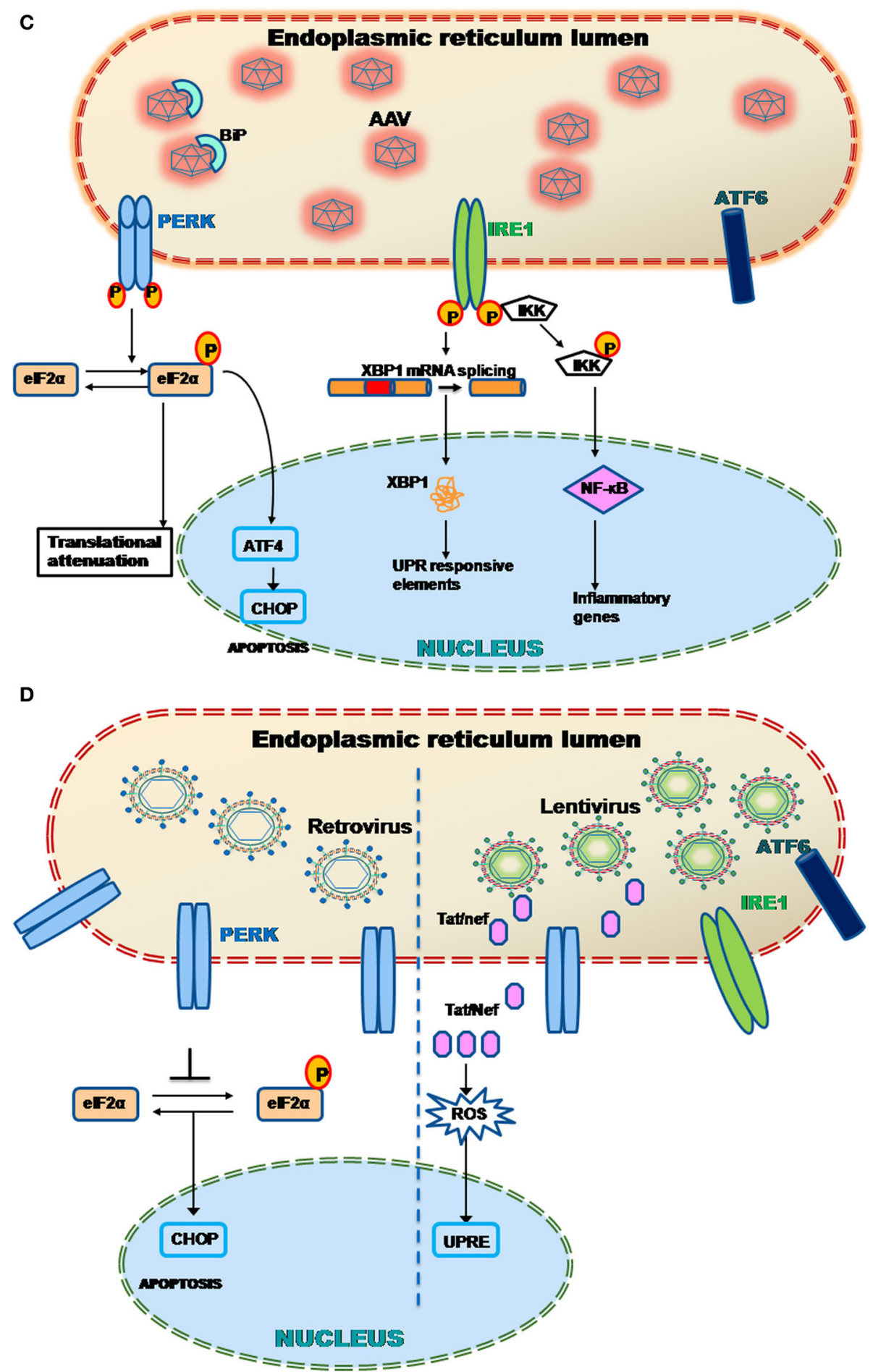

FIGURE 2 | (A) Herpes simplex virus (HSV-1) and UPR. HSV-1 produces proteins such as glycoprotein B (gB) and US11 that have been shown to evade the host UPR mechanism (Mulvey et al., 2003, 2007). In particular, the protein $\mathrm{gB}$ specifically binds to the PERK proteins preventing their phosphorylation. This leads to PERK inactivation and hence the downstream effector protein elF2 $\alpha$ could not get activated leading to ATF4 repression. Alternatively another viral protein called US11 represses the elF2 $\alpha$ phosphorylation by directly binding to it. The late HSV viral protein $\gamma_{1} 34.5$ also induces dephosphorylation of elF2 $\alpha$ with the help of the cellular phosphatase PP1 $\alpha$ (He et al., 1996). This leads to early repression of ATF4 and $\mathrm{CHOP}$ genes downstream. Thus the host UPR response is attenuated and leads to successful viral transduction. (B) Adenovirus (Ad) and UPR. Adenoviruses during their late phase of their infection, try to overcome the cellular stress response by preventing the shutdown of protein translation through PKR mediated inhibition of elF2 $\alpha$ phosphorylation via viral associated (Continued) 


\section{FIGURE 2 | Continued}

RNA molecule I (VAI RNA) as well as double-stranded RNA-activated inhibitor (DAI) (Huang and Schneider, 1990; Mathews and Shenk, 1991; McKenna et al., 2006). Other Ad proteins such as E1B and E4 has also been found to directly bind to the elF2 $\alpha$, thus preventing its phosphorylation and activation of downstream UPR related genes like ATF4 and CHOP (Spurgeon and Ornelles, 2009). (C) Adeno associated virus (AAV) and UPR. When the cellular ER encounters AAV particles, specific stress sensors, PERK and IRE1 gets activated (Balakrishnan et al., 2013). PERK phosphorylation leads to the activation of the elF2 $\alpha$ through phosphorylation. The phosphorylated elF2 $\alpha$ further activates the activating transcription factor 4 (ATF4) the protein of which translocates into the nucleus transcribing UPR responsive genes necessary to cope up with the cellular stress. The phosphorylated elF2 $\alpha$ also arrests the translation of cellular proteins to maintain homeostasis. It has been noted that the AAV particles also activates IRE1 which induces the unusual splicing of X-box binding protein 1 (XBP1) mRNA downstream. The $\mathrm{XBP} 1$ protein translocates into the nucleus activating a set of UPR responsive elements. The IRE1 also activates the IKK leading to NF-KB upregulation. The activated NF-KB further activates the inflammatory genes thus inducing an inflammatory response (Jayandharan et al., 2011; Balakrishnan et al., 2013). (D) Murine leukemia virus (MLV) and UPR. MLV based $\gamma$-retroviral vectors, which are the most common used in gene therapy, has been showed to induce neuropathogenecity in astrocytes (Dimcheff et al., 2003). Later in $\mathrm{NIH} 3 \mathrm{~T} 3$ cells it was shown that the murine retroviruses induce the ER stress related genes such as CHOP/GADD153 which leads to apoptosis (Dimcheff et al., 2003). On the other hand, the lentiviral proteins such as Tat and Nef have been shown to activate unfolded protein response elements (UPRE) by increasing ROS (Tiede et al., 2011; Abbas et al., 2012). repression (less that $24 \mathrm{~h}$ post infection) of ATF4 and CHOP due to inhibition of phosphorylation of eIF2 $\alpha$. ICP0, an immediateearly Ad gene product known to have transcription factor capabilities (Yao and Schaffer, 1994), was found to be the primary factor triggering activation of the UPR enhancers during HSV1 replication, thus helping the virus to sense it at an early stage. Consistent to a previous finding (Mulvey et al., 2003), XBP1(for the IRE1 signaling pathway) remained inactive in this study as well.

\section{Ad AND UPR}

Ads are non-enveloped DNA viruses whose genome is comprised of a linear $36 \mathrm{~kb}$ double-stranded DNA. The recombinant Ad vectors were first used as a gene transfer agent in 1985 (Ballay et al., 1985; Yamada et al., 1985) and since then have been used as a vehicle for various monogenic diseases (Porteus et al., 2006). For example, Ad vectors expressing cystic fibrosis transmembrane conductance regulator CFTR have been used in phase I clinical studies to treat cystic fibrosis (Zuckerman et al., 1999). Muscular dystrophy is another disease where attenuated Ad vectors have been used to deliver dystrophin cDNA into muscle tissue (Clemens et al., 1996; Haecker et al., 1996; Floyd et al., 1998). Improved Ad vectors have also been used to deliver human coagulation factors VIII and IX for phenotypic correction of hemophilia in preclinical animal models (Zhang, 1999). These vectors have been used in the treatment of several other metabolic and genetic diseases like lysosomal storage disease, phenylketonuria and glycogen storage disease (Amalfitano et al., 1999; Nagasaki et al., 1999; Ziegler et al., 1999; Eto and Ohashi, 2000; Stein et al., 2000; Zingone et al., 2000), neurological disorders like Parkinson/Alzheimer's as well as cardiovascular diseases like atherosclerosis, cerebral ischemia and in cancer therapy (Donahue et al., 2000; Papadopoulos et al., 2000; Choi and Yun, 2013).

As is the case of any foreign protein, Ad vectors are also subject to severe inflammatory response, which lead to their clearance and achieves only transient gene expression in the target tissue. One of the major transcription factor that serves as the mediator of inflammatory response is NF- $\mathrm{B}$, which can be activated by various pathological stimuli like bacterial/viral infection and the inflammatory cytokines. It has been shown previously that accumulation of protein load in the ER can activate NF-кB via the PERK and IRE-1 pathway (Tam et al., 2012). It has been demonstrated that the Ad E3/19 K protein can activate NF- $\kappa \mathrm{B}$ mediated by $\mathrm{Ca}^{2+}$ release from the ER following a protein overload, in vitro. As a result, NF- $\kappa \mathrm{B}$ activates inflammatory cytokines and interferons that constitute the initial anti-viral response of the cells (Pahl and Baeuerle, 1995). As with most viruses, in the late phase of productive infection, viral protein synthesis is promoted in Ad-infected cells while simultaneously inhibiting the cellular protein synthesis. One of the ways Ad does this, is by inhibition of PKR-mediated eIF $2 \alpha$ phosphorylation along with the activation of a protein kinase called double-stranded RNAactivated inhibitor (DAI) (Huang and Schneider, 1990). It has also been shown that the non-coding Ad associated RNA molecule I (VAI RNA) can suppress PKR activation by directly binding to it (Mathews and Shenk, 1991; McKenna et al., 2006). VAI RNA is highly expressed during the late phase of Ad infection when it is transcribed by a RNA polymerase III (Soderlund et al., 1976; Thimmappaya et al., 1982; Svensson and Akusjarvi, 1984). It plays a crucial role in preventing shutdown of cellular translational apparatus by inhibiting eIF $2 \alpha$ phosphorylation and the activation of PKR, although the precise mechanism remains unclear (Huang and Schneider, 1990). Spergeon et al., have also shown the role of Ad E1B 55-Kd and E4 Open Reading Frame 6 Proteins in promoting its infection in the late phase. These Ad proteins were shown to limit phosphorylation of eIF $2 \alpha$ phosphorylation and PKR activation (Figure 2B). This process requires the functioning of the Cul5-mediated E3 ubiquitin-protein ligase of the E1B$55 \mathrm{~K} / \mathrm{E} 4$ orf6 complex which is independent of the cytoplasmic levels of VAI RNA (Spurgeon and Ornelles, 2009).

\section{AAV AND UPR}

Naturally occurring AAV is small ( $22 \mathrm{~nm})$, non-enveloped and contains single-stranded DNA $(\sim 4.7 \mathrm{~kb})$. It belongs to the family Parvoviridae, and the genus Dependovirus (Balakrishnan and Jayandharan, 2014). The genome contains two open reading frames encoding the genes, rep (responsible for replication) and cap (encodes capsid specific proteins) flanked by a 145 base pair long inverted terminal repeat (ITR) sequence. AAV enters the infective cycle only in presence of other helper virus such as Ad or HSV (Daya and Berns, 2008). Recombinant AAV is produced by stuffing the transgene of interest between the flanking ITRs while the rep and cap genes are supplied in trans along with helper function genes (Wright, 2009). Currently, AAV is the choice vector for many inherited and non-inherited diseases 
because of its non-pathogenic nature. Another major advantage of using AAV as a gene therapy vector is its low immune profile when compared to Ad vectors (Asokan et al., 2012). So far 12 AAV serotypes (AAV1-12) has been used as gene therapy vectors although several other serovars are known to exist. AAV is naturally hepatotrophic that makes them an attractive choice for liver targeted gene therapy for the treatment of diseases such as hemophilia and alphal antitrypsin deficiency (Flotte et al., 2011; Nathwani et al., 2011). However several other alternate serotypes like AAV1, AAV5, AAV9, and rh10 have shown significant promise in targeting tissues like the muscle and the central nervous system (Zincarelli et al., 2008; Tang et al., 2010; Rafi et al., 2012; Gray et al., 2013). Unfortunately, the vector dose-dependent immune response and the presence of pre-existing neutralizing antibody against AAV capsids can limit persistent gene expression in humans (Manno et al., 2006; Boutin et al., 2010). It is known that $\mathrm{AAV}$, after receptor mediated endcocytosis, undergoes trafficking through the endocytic compartments followed by retrograde transport to the Golgi or the ER (Ding et al., 2005). It has been shown earlier that intracellular trafficking of AAV is negatively regulated by components of the ER stress response (Duan et al., 1999; Douar et al., 2001; Ding et al., 2003). For example AAV mediated human factor (F).VIII gene expression improved by $\sim 300-600 \%$ upon inhibiting the proteasomal machinery by using pharmacological agents like bortezomib in preclinical animal models of haemophilia (Monahan et al., 2010). Thus, it is quite logical to note that during intracellular trafficking, ER stress could play an inhibitory role in AAV life cycle. Indeed, we have recently shown the role of UPR in AAV infection (Balakrishnan et al., 2013). In this study self-complementary (sc) AAV2 was shown to activate the PERK and IRE-1 pathway in HeLa cells with peak activation $12 \mathrm{~h}$ post-infection. ATF6 however was not induced by scAAV2. Interestingly, single-stranded (ss) AAV2 did not induce UPR effectors as dominantly as scAAV2 although it modestly activated PERK and IRE-1. The activation of PERK and IRE-1 was further confirmed by an increased expression of downstream signaling molecules like CHOP and spliced XBP-1, respectively. Inhibiting PERK and or IRE-1 expression in in vitro (using shRNA against PERK/IRE-1) and in vivo (metformin, i.p) led to a modest increase in gene expression from scAAV2 vectors (Figure 2C). Interestingly, this study also found that alternate AAV serotype vectors like AAV1 and AAV6 can activate distinct arms of UPR. For example, scAAV6 had a comparable effect on PERK activation but not on IRE-1 as scAAV2 vectors. Another observation was the ablation of innate immune response markers following UPR inhibition in vivo. This clearly points to the link between UPR activation and clearing of the vectors through innate immune response. It has been shown previously that AAV can activate the classical NF- $\kappa B$ pathway during the acute phase of infection and trigger downstream inflammatory markers like TNF- $\alpha$, IL1a, IL6, and leading to the activation of the adaptive immune response (Jayandharan et al., 2011). It is also known that UPR caused by protein overload can activate cellular NF- $\kappa$ B in the early phase while it is inhibitory in the late phase (Kitamura, 2011) (Figure 2C). Thus, the UPR pathway becomes an important target to reduce inflammatory response in the early stages of AAV infection and to further enhance the persistence and gene expression from AAV vectors. Interestingly, the efficiency of AAV transduction is also known to improve under general cellular stress as shown earlier in cellular models of cystic fibrosis (Johnson et al., 2011).

\section{RETRO-/LENTI-VIRUS AND UPR}

Historically, vectors based on retrovirus which were the first viral vector system described in the early 1980s (Douar et al., 2001) have been the most preferred in clinical gene therapy due to their properties of efficient host DNA integration and persistent gene expression. However, in the clinical trial involving infants with $\mathrm{X}$-SCID, 4 out of 9 patients developed leukemia due to random retroviral integration, this remains a major concern with retrovirus based gene therapy (Cavazzana-Calvo et al., 2000; Kohn et al., 2003). Lentivirus, that belongs to the retroviridae family is also known to facilitate stable integration of the viral genome into the host chromosome. Over the past decade, more than 30 patients with different immunodeficiency disorders have been treated successfully using murine leukemia virus (MLV)-based $\gamma$-retroviral vectors to transfer therapeutic genes to autologous hematopoietic cells (Aiuti et al., 2002; Aiuti and Roncarolo, 2009). However, random integration of the lentiviral vectors is also known (Wang et al., 2009a). Although not many studies have been conducted to understand if and how retro- or lenti-viruses combat UPR, there is some evidence that retroviruses can induce ER stress. In Shikova et al. (1993) first showed in cultured astrocytes that neuropathogenicity of MLV viruses may be related to protein misfolding in the ER (Shikova et al., 1993). In Dimcheff et al. (2003) demonstrated that a mouse retrovirus $\mathrm{FrCas}^{\mathrm{E}}$ is able to induce ER stress related genes like CHOP/GADD153 and Bip in vitro in NIH3T3 cells as well as in vivo which correlated with the induction of spongiform neurodegeneration (Figure 2D) (Dimcheff et al., 2003). Similarly, mink cell focusforming murine leukemia virus (MCF13 MLV) has been shown to trigger UPR in mink cells following large accumulation of the viral protein MLV gPr80 env via upregulation of CHOP proteins (Nanua and Yoshimura, 2004). A Lentivirus-HIV-1 protein called the trans-activator of transcription (Tat) has been reported to induce UPR by increasing reactive oxygen species (ROS) in primary rat striatal neurons indicating that ER stress response could be a critical parameter to control during HIV infection (Figure 2D) (Tiede et al., 2011). Another HIV viral protein called Nef, known to increase infectivity and replication in lymphocytes and macrophages has been shown to directly interact with the eukaryotic elongation factor (eEF)-1 $\alpha$ resulting in its cytoplasmic relocalization and the inhibition of stress-induced apoptosis. Conversely, the nuclear re-localization of the Nef/eEF1 $\alpha$ complex can decrease mitochondrial cytochrome $c$ release, thereby inhibiting the caspase activation. This mechanism demonstrates how the lentivirus (HIV) can prevent cell death under conditions of stress condition yet is able to create an environment favoring optimal viral replication (Abbas et al., 2012) (Figure 2D). Another unique retrovirus called Foamy viruses (FVs) have also been extensively studied as a gene therapy vector due to their lack of pathogenicity, broad tissue tropism and the ability to carry large (minimum $\sim 9.2 \mathrm{~kb}$ ) transgenes (Heneine et al., 2003; Trobridge, 2009). Hematopoietic stem cell (HSC) gene therapy is one area 
where FVs have been extensively evaluated with considerable success (Josephson et al., 2004; Bauer et al., 2008). However there are no published evidence which have studied the interaction between FVs and cellular UPR. However it is possible that like other retro-/lenti- viruses, FVs would have developed mechanism to either counteract or utilize the UPR machinery to enhance its own replication in the infected cells.

\section{OTHER VIRAL VECTORS AND UPR}

In addition to the commonly used viral vectors described above, attempts have been made to utilize other viruses as vectors for certain disease conditions. For example, Vaccinia viral vectors have been in use as a potential therapeutic for cancer gene therapy (Yu et al., 2009; Seubert et al., 2011) mainly because of its efficient infection and gene expression in a wide range of difficult to transduce tumors (Yu et al., 2004) as well as their inability to integrate into the chromosome (Shen and Nemunaitis, 2005). Also, the safety profile of Vaccinia virus as a therapeutic agent is well understood due to its long and widespread use as a vaccine for small pox in humans. Like most viruses, vaccinia virus also regulates the cellular UPR machinery to facilitate its infection. For example, a vaccinia viral protein $\mathrm{K} 3 \mathrm{~L}$ which has $\sim 28 \%$ sequence identity with eIF-2a is thought to function as a pseudo substrate for its kinase, thus blocking the PKR activity and leading to the inhibition of PERK and eIF2 $\alpha$ molecules (Sood et al., 2000). Following ER stress response, another Vaccinia protein called F1L can indirectly inhibit the activation of the apoptotic protein Baxby by interacting with the proapoptotic $\mathrm{BH} 3$-only proteins through Bak and Bax (Taylor et al., 2006).

Varicella zoster virus (VZV), the causative agent of varicella (chickenpox) and zoster (shingles) and a member of the Herpesviridae family has also been tested as a cancer gene therapy vector (Degreve et al., 1997). VZV has been shown to induce cellular UPR through ER stress in vitro. It has been shown to activate both the IRE-1 and the CHOP pathway and ultimately leads to autophagy (Carpenter et al., 2011). This study also confirmed that the VZV structural glycoproteins—gE (ORF68), gI (ORF67), $\mathrm{gH}$ (ORF37), and gL (ORF60) were enough to induce UPR during an active viral infection.

Epstein-Barr virus (EBV) is a member of the Herpesviridae family that has a natural tropism for $\mathrm{B}$ cells. This property of the virus has been utilized to deliver GM-CSF to human B cells from B-cell chronic lymphocytic leukemia (B-CLL) patients as a potential immune therapy (Hellebrand et al., 2006). However, since $\mathrm{EBV}$ is associated with a number of human malignancies, rigorous vector modification and validation is called for prior to its application as a gene delivery vehicle in humans. The latent membrane protein 1 (LMP1) oncogene of EBV is shown to induce the phosphorylation of eIF $2 \alpha$ by activating all the three arms of UPR, the PERK, IRE-1, and ATF6 pathways. This activation in turn up-regulates LMP1, which leads to induction and maintenance of the proliferating B lymphocytes (Lee and Sugden, 2008). Thus it seems that the UPR pathway is required for EBV to enter into its lytic stage toward maintaining its proliferative and infectious life-cycle (Taylor et al., 2011).

Sendai virus $(\mathrm{SeV})$ is a negative strand RNA virus which utilizes sialic acid residue or a sialoglycoprotein as their receptor for cell entry (Markwell et al., 1981). The major advantages of using recombinant $\mathrm{SeV}$ as a gene therapy vector is its nonpathogenicity and the ability to be generated in high titre during packaging process. Preclinical studies have shown that $\mathrm{SeV}$ can transduce different cell types like vascular tissue (Masaki et al., 2001), skeletal muscle (Shiotani et al., 2001), airway epithelial cells (Yonemitsu et al., 2000) and synovial cells (Yamashita et al., 2002), quite efficiently. Further, it has been shown that SeV vector can efficiently transfer its cargo to $\mathrm{CD} 34^{+}$cell and $\mathrm{CD} 34^{+}$ cell subpopulations derived from human cord blood (Jin et al., 2003). In addition, $\mathrm{SeV}$ was also able to get stable gene expression in myeloid, erythroid or mixed progenitor cells (Jin et al., 2003). However, since SeV induces cytopathic effects in infected cells, toxicity concerns remain. $\mathrm{SeV}$ has been shown to upregulate CXCL2 protein following ER stress, which can lead to cell death via activation of caspase- 8 and caspase- 3 mediated apoptosis (Bitzer et al., 1999; Versteeg et al., 2007). It is also thought that this virus can activate eIF2 $\alpha$ kinases like PERK and PKR to induce IFN regulatory factor (IRF) 7, a major player in host antiviral innate response. ATF4, another key regulator of cellular response to viral infection can be upregulated via phosphorylation of eIF $2 \alpha$ and the activation of IRF7 ultimately helping in cellular recovery (Liang et al., 2011).

Alphavirus vectors based on Sindbisvirus (SINV) and Semliki Forest virus (SFV) is another group of virus that has been evaluated as a gene therapy vector because of advantages like broad host range, efficient replication in the cytoplasm and the capacity to produce high levels of recombinant proteins. Several preclinical studies have been conducted so far to evaluate the efficiency of alphaviruses as a gene transfer vehicle. For example, SFV was shown to transduce cardiovascular cells as well as human tumor cells to deliver IL-12 (Roks et al., 1997; Zhang et al., 1997). Alphaviral vectors have also been looked upon as a potential delivery vehicle for DNA-based vaccines (Berglund et al., 1997, 1998). More recently, SFV was used for gene transfer into the central nervous system but was also toxic (Graham et al., 2006). In mammalian cells, SFV envelope glycoproteins activate the UPR response through induction of CHOP proteins and its consequent upregulation of caspase-3, caspase-8, and caspase-9 apoptotic enzymes (Barry et al., 2010). SFV has also been shown to have delayed RNA synthesis in the presence of Brefeldin A, a potent UPR inducer (Molina et al., 2007). Another report suggests that PERK can suppress SFV viral replication at an early stage by eliciting strong interferon response in the mouse brain (Barry et al., 2009). One study revealed that the alpha virus SINV could activate PERK and IRE- 1 but not the ATF6 within $48 \mathrm{~h}$ of infection in vitro. In this study, SINV uncontrollably activated the UPR by phosphorylation of eIF2 $\alpha$ and leading to apoptosis (Rathore et al., 2013). Moreover SINV has been shown to promote autophagy in neuronal cells both in in vitro and in vivo probably via activation of the UPR pathways, thus limiting the spread of viral infection (Orvedahl et al., 2010; Shi and Luo, 2012).

\section{STRATEGIES TO INHIBIT UPR AGAINST VIRUSES USED IN GENE TRANSFER}

One of the ways to inhibit UPR is through small molecule inhibitors, which can repress the cellular proteasomal machinery. 
For example, the use of pharmacological agents that inhibit proteasomes like metformin, MG-132, and ricin has been previously shown to reduce cellular UPR (Lee et al., 2003; Parikh et al., 2008; Amanso et al., 2011; Theriault et al., 2011). We have previously shown that scAAV2 upregulates PERK and IRE$1 \alpha$ genes in murine liver, $\sim 24 \mathrm{~h}$ post vector administration (Balakrishnan et al., 2013). This effect was reversed when animals were pretreated with metformin $(250 \mathrm{mg} / \mathrm{kg})$. More importantly, it was also found that attenuation of the UPR response against AAV also inhibited the expression of various inflammatory cytokines and chemokines like Chemokine (C-C motif) ligand 12 (Ccl12), Chemokine (C-C motif) ligand 11 (Ccl11), Chemokine (C-C motif) ligand $22(\mathrm{Ccl} 22)$, Chemokine C-X-C motif ligand 13 (CXCL13), Chemokine (C-C motif) ligand $24(\mathrm{Ccl} 24)$, Chemokine C-C motif receptor 2 (Ccr2) and chemokine C-X-C motif ligand 15 (CXCL15) (Balakrishnan et al., 2013). Thus, inhibiting the UPR by proteasomal repressors could potentially reduce innate immune response against AAV leading to higher and probably persistent gene expression. However, it is a known fact that systemic administration of proteasomal inhibitors can have adverse effects (Rajkumar et al., 2005). It is however conceivable that transient inhibition of UPR pathways prior to gene transfer and during the initial period of viral infection might lead to improved gene transfer efficiency. Another way to repress UPR could be by the use of silencing (si) RNAs against specific components of the UPR pathway. Our study had previously shown a modest increase in transgene expression from AAV vectors when the PERK and IRE-1 $\alpha$ pathways were inhibited by specific siRNA in vitro (Balakrishnan et al., 2013). shRNAs against UPR components can also be potentially tested in vivo. Such shRNAs can be delivered under inducible promoters to avoid adverse effects caused by long term suppression of UPR machinery.

To avoid immune mediated clearance of viral vectors during gene therapy, ideally the vector dose should be kept to the minimum. This would allow the vectors to not only to escape the host immune surveillance before entering the target cells, but may also reduce cellular stress. To this end, vector bioengineering becomes a very important tool by which novel, optimized vectors can be created as described earlier with AAV (Markusic et al., 2010; Qiao et al., 2010; Gabriel et al., 2013; Sen et al., 2013a,b) to achieve efficient gene transfer at lower vector doses.

\section{CONCLUSIONS}

In higher eukaryotes, UPR is a beneficial process that protects the cell from undue stress. Cellular UPR strives to reduce the burden on the ER by enhancing its capacity with the help of several stress response chaperones. If this process becomes futile, UPR can induce apoptosis of the host cell. Most viruses reprogram the cellular translational machinery to facilitate the generation of their proteins, but this process can also trigger the UPR pathways, which consequently may lead to cell death. For successful gene therapy, the survival of the transduced cells is very important to achieve sustained gene expression. In this scenario, transient inhibition of UPR prior to gene transfer, by strategies discussed above, provides an attractive alternative to improving the safety and efficiency of viral gene therapy. However, further detailed understanding of the sub-cellular processes that activate UPR against such viral vectors is also necessary to tailor specific strategies and to shift the balance in favor of virus persistence in the host without compromising either of their survival.

\section{ACKNOWLEDGMENTS}

Balaji Balakrishnan is supported by a junior research fellowship from university grants commission (UGC), Government of India. Giridhara R. Jayandharan is supported by research grants from Department of Science of Technology, Government of India (Swarnajayanti Fellowship 2011), Department of Biotechnology (DBT), Government of India (Innovative Young Biotechnologist award 2010: BT/03/IYBA/2010; Grant: BT/PR14748/MED/12/491/2010; Grant: BT/01/COE/08/03; Grant BT/PR5021/MED/30/757/2012) and an early career investigator award-2010 from Bayer Hemophilia Awards program, Bayer Inc, USA.

\section{REFERENCES}

Abbas, W., Khan, K. A., Tripathy, M. K., Dichamp, I., Keita, M., Rohr, O., et al. (2012). Inhibition of ER stress-mediated apoptosis in macrophages by nuclearcytoplasmic relocalization of eEF1A by the HIV-1 Nef protein. Cell Death. Dis. 3, e292. doi: 10.1038/cddis.2012.32

Aiuti, A., and Roncarolo, M. G. (2009). Ten years of gene therapy for primary immune deficiencies. Hematology Am. Soc. Hematol. Educ. Program 682-689. doi: 10.1182/asheducation-2009.1.682

Aiuti, A., Slavin, S., Aker, M., Ficara, F., Deola, S., Mortellaro, A., et al. (2002). Correction of ADA-SCID by stem cell gene therapy combined with nonmyeloablative conditioning. Science 296, 2410-2413. doi: 10.1126/science. 1070104

Amalfitano, A., McVie-Wylie, A. J., Hu, H., Dawson, T. L., Raben, N., Plotz, P., et al. (1999). Systemic correction of the muscle disorder glycogen storage disease type II after hepatic targeting of a modified adenovirus vector encoding human acid-alpha-glucosidase. Proc. Natl. Acad. Sci. U.S.A. 96, 8861-8866. doi: 10.1073/pnas.96.16.8861

Amanso, A. M., Debbas, V., and Laurindo, F. R. (2011). Proteasome inhibition represses unfolded protein response and Nox4, sensitizing vascular cells to endoplasmic reticulum stress-induced death. PLoS ONE 6:e14591. doi: 10.1371/journal.pone.0014591

Anelli, T., and Sitia, R. (2008). Protein quality control in the early secretory pathway. EMBO J. 27, 315-327. doi: 10.1038/sj.emboj.7601974

Arii, J., Uema, M., Morimoto, T., Sagara, H., Akashi, H., Ono, E., et al. (2009). Entry of herpes simplex virus 1 and other alphaherpesviruses via the paired immunoglobulin-like type 2 receptor alpha. J. Virol. 83, 4520-4527. doi: 10.1128/JVI.02601-08

Asokan, A., Schaffer, D. V., and Samulski, R. J. (2012). The AAV vector toolkit: poised at the clinical crossroads. Mol. Ther. 20, 699-708. doi: $10.1038 / \mathrm{mt} .2011 .287$

Balakrishnan, B., and Jayandharan, G. R. (2014). Basic biology of adeno-associated virus (AAV) vectors used in gene therapy. Curr. Gene Ther. 14, 1-15. doi: $10.2174 / 1566523214666140302193709$

Balakrishnan, B., Sen, D., Hareendran, S., Roshini, V., David, S., Srivastava, A., et al. (2013). Activation of the cellular unfolded protein response by recombinant adeno-associated virus vectors. PLoS ONE 8:e53845. doi: 10.1371/journal.pone.0053845

Ballay, A., Levrero, M., Buendia, M. A., Tiollais, P., and Perricaudet, M. (1985). In vitro and in vivo synthesis of the hepatitis $\mathrm{B}$ virus surface antigen and of the receptor for polymerized human serum albumin from recombinant human adenoviruses. EMBO J. 4, 3861-3865.

Barry, G., Breakwell, L., Fragkoudis, R., Attarzadeh-Yazdi, G., Rodriguez-Andres, J., Kohl, A., et al. (2009). PKR acts early in infection to suppress Semliki Forest virus production and strongly enhances the type I interferon response. J. Gen. Virol. 90, 1382-1391. doi: 10.1099/vir.0.007336-0

Barry, G., Fragkoudis, R., Ferguson, M. C., Lulla, A., Merits, A., Kohl, A., et al. (2010). Semliki forest virus-induced endoplasmic reticulum stress accelerates apoptotic death of mammalian cells. J. Virol. 84, 7369-7377. doi: 10.1128/JVI.02310-09 
Bauer, T. R. Jr., Allen, J. M., Hai, M., Tuschong, L. M., Khan, I. F., Olson, E. M., et al. (2008). Successful treatment of canine leukocyte adhesion deficiency by foamy virus vectors. Nat. Med. 14, 93-97. doi: 10.1038/nm1695

Berglund, P., Quesada-Rolander, M., Putkonen, P., Biberfeld, G., Thorstensson, R., and Liljestrom, P. (1997). Outcome of immunization of cynomolgus monkeys with recombinant Semliki Forest virus encoding human immunodeficiency virus type 1 envelope protein and challenge with a high dose of SHIV-4 virus. AIDS Res. Hum. Retroviruses 13, 1487-1495. doi: 10.1089/aid.1997.13.1487

Berglund, P., Smerdou, C., Fleeton, M. N., Tubulekas, I., and Liljestrom, P. (1998). Enhancing immune responses using suicidal DNA vaccines. Nat. Biotechnol. 16, 562-565. doi: 10.1038/nbt0698-562

Bernales, S., McDonald, K. L., and Walter, P. (2006). Autophagy counterbalances endoplasmic reticulum expansion during the unfolded protein response. PLoS Biol. 4:e423. doi: 10.1371/journal.pbio.0040423

Bertolotti, A., Wang, X., Novoa, I., Jungreis, R., Schlessinger, K., Cho, J. H., et al. (2001). Increased sensitivity to dextran sodium sulfate colitis in IRElbetadeficient mice. J. Clin. Invest. 107, 585-593. doi: 10.1172/JCI11476

Bertolotti, A., Zhang, Y., Hendershot, L. M., Harding, H. P., and Ron, D. (2000). Dynamic interaction of $\mathrm{BiP}$ and $\mathrm{ER}$ stress transducers in the unfolded-protein response. Nat. Cell Biol. 2, 326-332. doi: 10.1038/35014014

Bitko, V., and Barik, S. (2001). An endoplasmic reticulum-specific stress-activated caspase (caspase-12) is implicated in the apoptosis of A549 epithelial cells by respiratory syncytial virus. J. Cell. Biochem. 80, 441-454. doi: 10.1002/10974644(20010301)80:3<441::AID-JCB170>3.0.CO;2-C

Bitzer, M., Prinz, F., Bauer, M., Spiegel, M., Neubert, W. J., Gregor, M., et al. (1999). Sendai virus infection induces apoptosis through activation of caspase-8 (FLICE) and caspase-3 (CPP32). J. Virol. 73, 702-708.

Boutin, S., Monteilhet, V., Veron, P., Leborgne, C., Benveniste, O., Montus, M. F., et al. (2010). Prevalence of serum IgG and neutralizing factors against adenoassociated virus (AAV) types $1,2,5,6,8$, and 9 in the healthy population: implications for gene therapy using AAV vectors. Hum. Gene Ther. 21, 704-712. doi: 10.1089/hum.2009.182

Burnett, H. F., Audas, T. E., Liang, G., and Lu, R. R. (2012). Herpes simplex virus-1 disarms the unfolded protein response in the early stages of infection. Cell Stress Chaperones 17, 473-483. doi: 10.1007/s12192-012-0324-8

Carpenter, J. E., Jackson, W., Benetti, L., and Grose, C. (2011). Autophagosome formation during varicella-zoster virus infection following endoplasmic reticulum stress and the unfolded protein response. J. Virol. 85, 9414-9424. doi: 10.1128/JVI.00281-11

Cassady, K. A., Gross, M., and Roizman, B. (1998). The herpes simplex virus US11 protein effectively compensates for the gammal(34.5) gene if present before activation of protein kinase $\mathrm{R}$ by precluding its phosphorylation and that of the alpha subunit of eukaryotic translation initiation factor 2. J. Virol. 72, 8620-8626.

Cavazzana-Calvo, M., Hacein-Bey, S., De Saint Basile, G., Gross, F., Yvon, E., Nusbaum, P., et al. (2000). Gene therapy of human severe combined immunodeficiency (SCID)-X1 disease. Science 288, 669-672. doi: 10.1126/science.288.5466.669

Choi, I. K., and Yun, C. O. (2013). Recent developments in oncolytic adenovirusbased immunotherapeutic agents for use against metastatic cancers. Cancer Gene Ther. 20, 70-76. doi: 10.1038/cgt.2012.95

Clemens, P. R., Kochanek, S., Sunada, Y., Chan, S., Chen, H. H., Campbell, K. P., et al. (1996). In vivo muscle gene transfer of full-length dystrophin with an adenoviral vector that lacks all viral genes. Gene Ther. 3, 965-972.

Cox, J. S., Shamu, C. E., and Walter, P. (1993). Transcriptional induction of genes encoding endoplasmic reticulum resident proteins requires a transmembrane protein kinase. Cell 73, 1197-1206. doi: 10.1016/0092-8674(93)90648-A

Daya, S., and Berns, K. I. (2008). Gene therapy using adeno-associated virus vectors. Clin. Microbiol. Rev. 21, 583-593. doi: 10.1128/CMR.00008-08

Degreve, B., Andrei, G., Izquierdo, M., Piette, J., Morin, K., Knaus, E. E., et al. (1997). Varicella-zoster virus thymidine kinase gene and antiherpetic pyrimidine nucleoside analogues in a combined gene/chemotherapy treatment for cancer. Gene Ther. 4, 1107-1114. doi: 10.1038/sj.gt.3300502

Dimcheff, D. E., Askovic, S., Baker, A. H., Johnson-Fowler, C., and Portis, J. L. (2003). Endoplasmic reticulum stress is a determinant of retrovirusinduced spongiform neurodegeneration. J. Virol. 77, 12617-12629. doi: 10.1128/JVI.77.23.12617-12629.2003

Ding, W., Yan, Z., Zak, R., Saavedra, M., Rodman, D. M., and Engelhardt, J. F. (2003). Second-strand genome conversion of adeno-associated virus type 2
(AAV-2) and AAV-5 is not rate limiting following apical infection of polarized human airway epithelia. J. Virol. 77, 7361-7366. doi: 10.1128/JVI.77.13.73617366.2003

Ding, W., Zhang, L., Yan, Z., and Engelhardt, J. F. (2005). Intracellular trafficking of adeno-associated viral vectors. Gene Ther. 12, 873-880. doi: 10.1038/sj.gt.3302527

Donahue, J. K., Heldman, A. W., Fraser, H., McDonald, A. D., Miller, J. M., Rade, J. J., et al. (2000). Focal modification of electrical conduction in the heart by viral gene transfer. Nat. Med. 6, 1395-1398. doi: 10.1038/82214

Douar, A. M., Poulard, K., Stockholm, D., and Danos, O. (2001). Intracellular trafficking of adeno-associated virus vectors: routing to the late endosomal compartment and proteasome degradation. J. Virol. 75, 1824-1833. doi: 10.1128/JVI.75.4.1824-1833.2001

Duan, D., Li, Q., Kao, A. W., Yue, Y., Pessin, J. E., and Engelhardt, J. F. (1999). Dynamin is required for recombinant adeno-associated virus type 2 infection. J. Virol. 73, 10371-10376.

Epstein, A. L. (2009). HSV-1-derived amplicon vectors: recent technological improvements and remaining difficulties-a review. Mem. Inst. Oswaldo Cruz 104, 399-410. doi: 10.1590/S0074-02762009000300002

Eto, Y., and Ohashi, T. (2000). Gene therapy/cell therapy for lysosomal storage disease. J. Inherit. Metab. Dis. 23, 293-298. doi: 10.1023/A:1005692215317

Fan, Q., Lin, E., Satoh, T., Arase, H., and Spear, P. G. (2009). Differential effects on cell fusion activity of mutations in herpes simplex virus 1 glycoprotein B (gB) dependent on whether a $\mathrm{gD}$ receptor or a $\mathrm{gB}$ receptor is overexpressed. J. Virol. 83, 7384-7390. doi: 10.1128/JVI.00087-09

Flotte, T. R., Trapnell, B. C., Humphries, M., Carey, B., Calcedo, R., Rouhani, F., et al. (2011). Phase 2 clinical trial of a recombinant adeno-associated viral vector expressing alphal-antitrypsin: interim results. Hum. Gene Ther. 22, 1239-1247. doi: 10.1089 /hum.2011.053

Floyd, S. S. Jr., Clemens, P. R., Ontell, M. R., Kochanek, S., Day, C. S., Yang, J., et al. (1998). Ex vivo gene transfer using adenovirus-mediated full-length dystrophin delivery to dystrophic muscles. Gene Ther. 5, 19-30. doi: 10.1038/sj.gt.3300549

Gabriel, N., Hareendran, S., Sen, D., Gadkari, R. A., Sudha, G., Selot, R., et al. (2013). Bioengineering of AAV2 capsid at specific serine, threonine, or lysine residues improves its transduction efficiency in vitro and in vivo. Hum. Gene Ther. Methods 24, 80-93. doi: 10.1089/hgtb.2012.194

Gaudet, D., Methot, J., and Kastelein, J. (2012). Gene therapy for lipoprotein lipase deficiency. Curr. Opin. Lipidol. 23, 310-320. doi: 10.1097/MOL.0b013e3283555a7e

Graham, A., Walker, R., Baird, P., Hahn, C. N., and Fazakerley, J. K. (2006). CNS gene therapy applications of the Semliki Forest virus 1 vector are limited by neurotoxicity. Mol. Ther. 13, 631-635. doi: 10.1016/j.ymthe.2005.10.020

Gray, S. J., Nagabhushan Kalburgi, S., McCown, T. J., and Jude Samulski, R. (2013). Global CNS gene delivery and evasion of anti-AAV-neutralizing antibodies by intrathecal AAV administration in non-human primates. Gene Ther. 20, 450-459. doi: 10.1038/gt.2012.101

Haecker, S. E., Stedman, H. H., Balice-Gordon, R. J., Smith, D. B., Greelish, J. P., Mitchell, M. A., et al. (1996). In vivo expression of full-length human dystrophin from adenoviral vectors deleted of all viral genes. Hum. Gene Ther. 7, 1907-1914. doi: 10.1089/hum.1996.7.15-1907

Hai, T. W., Liu, F., Coukos, W. J., and Green, M. R. (1989). Transcription factor ATF cDNA clones: an extensive family of leucine zipper proteins able to selectively form DNA-binding heterodimers. Genes Dev. 3, 2083-2090. doi: $10.1101 / \mathrm{gad} .3 .12 \mathrm{~b} .2083$

Harding, H. P., Zhang, Y., and Ron, D. (1999). Protein translation and folding are coupled by an endoplasmic-reticulum-resident kinase. Nature 397, 271-274. doi: $10.1038 / 16729$

Harding, H. P., Zhang, Y., Zeng, H., Novoa, I., Lu, P. D., Calfon, M., et al. (2003). An integrated stress response regulates amino acid metabolism and resistance to oxidative stress. Mol. Cell 11, 619-633. doi: 10.1016/S1097-2765(03)00105-9

Haze, K., Okada, T., Yoshida, H., Yanagi, H., Yura, T., Negishi, M., et al. (2001). Identification of the G13 (cAMP-response-element-binding protein-related protein) gene product related to activating transcription factor 6 as a transcriptional activator of the mammalian unfolded protein response. Biochem. J. 355, 19-28. doi: 10.1042/0264-6021:3550019

Haze, K., Yoshida, H., Yanagi, H., Yura, T., and Mori, K. (1999). Mammalian transcription factor ATF6 is synthesized as a transmembrane protein and activated by proteolysis in response to endoplasmic reticulum stress. Mol. Biol. Cell 10, 3787-3799. doi: 10.1091/mbc.10.11.3787 
He, B. (2006). Viruses, endoplasmic reticulum stress, and interferon responses. Cell Death Differ. 13, 393-403. doi: 10.1038/sj.cdd.4401833

He, B., Chou, J., Liebermann, D. A., Hoffman, B., and Roizman, B. (1996). The carboxyl terminus of the murine MyD116 gene substitutes for the corresponding domain of the gamma (1)34.5 gene of herpes simplex virus to preclude the premature shutoff of total protein synthesis in infected human cells. J. Virol. 70, 84-90.

Hellebrand, E., Mautner, J., Reisbach, G., Nimmerjahn, F., Hallek, M., Mocikat, R., et al. (2006). Epstein-Barr virus vector-mediated gene transfer into human B cells: potential for antitumor vaccination. Gene Ther. 13, 150-162. doi: 10.1038/sj.gt. 3302602

Heneine, W., Schweizer, M., Sandstrom, P., and Folks, T. (2003). Human infection with foamy viruses. Curr. Top. Microbiol. Immunol. 277, 181-196. doi: 10.1007/978-3-642-55701-9_8

Hetz, C. (2012). The unfolded protein response: controlling cell fate decisions under ER stress and beyond. Nat. Rev. Mol. Cell Biol. 13, 89-102. doi: $10.1038 / \mathrm{nrm} 3270$

Hetz, C., Martinon, F., Rodriguez, D., and Glimcher, L. H. (2011). The unfolded protein response: integrating stress signals through the stress sensor IRE1alpha. Physiol. Rev. 91, 1219-1243. doi: 10.1152/physrev.00001.2011

Hoyer-Hansen, M., Bastholm, L., Szyniarowski, P., Campanella, M., Szabadkai, G., Farkas, T., et al. (2007). Control of macroautophagy by calcium, calmodulin-dependent kinase kinase-beta, and Bcl-2. Mol. Cell 25, 193-205. doi: $10.1016 /$ j.molcel.2006.12.009

Hu, J. C., and Coffin, R. S. (2003). Oncolytic herpes simplex virus for tumor therapy. Int. Rev. Neurobiol. 55, 165-184. doi: 10.1016/S0074-7742(03)01007-9

Huang, J. T., and Schneider, R. J. (1990). Adenovirus inhibition of cellular protein synthesis is prevented by the drug 2-aminopurine. Proc. Natl. Acad. Sci. U.S.A. 87, 7115-7119. doi: 10.1073/pnas.87.18.7115

Isler, J. A., Skalet, A. H., and Alwine, J. C. (2005). Human cytomegalovirus infection activates and regulates the unfolded protein response. J. Virol. 79, 6890-6899. doi: 10.1128/JVI.79.11.6890-6899.2005

Iwata, Y., and Koizumi, N. (2012). Plant transducers of the endoplasmic reticulum unfolded protein response. Trends Plant. Sci. 17, 720-727. doi: 10.1016/j.tplants.2012.06.014

Jayandharan, G. R., Aslanidi, G., Martino, A. T., Jahn, S. C., Perrin, G. Q., Herzog, R. W., et al. (2011). Activation of the NF-kappaB pathway by adeno-associated virus (AAV) vectors and its implications in immune response and gene therapy. Proc. Natl. Acad. Sci. U.S.A. 108, 3743-3748. doi: 10.1073/pnas.1012753108

Jin, C. H., Kusuhara, K., Yonemitsu, Y., Nomura, A., Okano, S., Takeshita, H., et al. (2003). Recombinant Sendai virus provides a highly efficient gene transfer into human cord blood-derived hematopoietic stem cells. Gene Ther. 10, 272-277. doi: 10.1038/sj.gt.3301877

Johnson, J. S., Gentzsch, M., Zhang, L., Ribeiro, C. M., Kantor, B., Kafri, T., et al. (2011). AAV exploits subcellular stress associated with inflammation, endoplasmic reticulum expansion, and misfolded proteins in models of cystic fibrosis. PLoS Pathog. 7:e1002053. doi: 10.1371/journal.ppat.1002053

Josephson, N. C., Trobridge, G., and Russell, D. W. (2004). Transduction of long-term and mobilized peripheral blood-derived NOD/SCID repopulating cells by foamy virus vectors. Hum. Gene Ther. 15, 87-92. doi: $10.1089 / 10430340460732481$

Kamimoto, T., Shoji, S., Hidvegi, T., Mizushima, N., Umebayashi, K., Perlmutter, D. H., et al. (2006). Intracellular inclusions containing mutant alphal-antitrypsin $\mathrm{Z}$ are propagated in the absence of autophagic activity. J. Biol. Chem. 281, 4467-4476. doi: 10.1074/jbc.M509409200

Kaufman, R. J., Scheuner, D., Schroder, M., Shen, X., Lee, K., Liu, C. Y., et al. (2002). The unfolded protein response in nutrient sensing and differentiation. Nat. Rev. Mol. Cell Biol. 3, 411-421. doi: 10.1038/nrm829

Kay, M. A. (2011). State-of-the-art gene-based therapies: the road ahead. Nat. Rev. Genet. 12, 316-328. doi: 10.1038/nrg2971

Khanna, A., and Campbell, R. D. (1996). The gene G13 in the class III region of the human MHC encodes a potential DNA-binding protein. Biochem. J. 319(Pt 1), $81-89$.

Kim, I., Xu, W., and Reed, J. C. (2008). Cell death and endoplasmic reticulum stress: disease relevance and therapeutic opportunities. Nat. Rev. Drug Discov. 7, 1013-1030. doi: 10.1038/nrd2755

Kitamura, M. (2011). Control of NF-kappaB and inflammation by the unfolded protein response. Int. Rev. Immunol. 30, 4-15. doi: $10.3109 / 08830185.2010 .522281$
Kohn, D. B., Sadelain, M., and Glorioso, J. C. (2003). Occurrence of leukaemia following gene therapy of X-linked SCID. Nat. Rev. Cancer 3, 477-488. doi: $10.1038 /$ nrc1 122

Kouroku, Y., Fujita, E., Tanida, I., Ueno, T., Isoai, A., Kumagai, H., et al. (2007). ER stress (PERK/eIF2alpha phosphorylation) mediates the polyglutamine-induced LC3 conversion, an essential step for autophagy formation. Cell Death Differ. 14, 230-239. doi: 10.1038/sj.cdd.4401984

Krisky, D. M., Marconi, P. C., Oligino, T. J., Rouse, R. J., Fink, D. J., Cohen, J. B., et al. (1998). Development of herpes simplex virus replication-defective multigene vectors for combination gene therapy applications. Gene Ther. 5, 1517-1530. doi: $10.1038 /$ sj.gt. 3300755

Lee, A. H., Iwakoshi, N. N., Anderson, K. C., and Glimcher, L. H. (2003). Proteasome inhibitors disrupt the unfolded protein response in myeloma cells. Proc. Natl. Acad. Sci. U.S.A. 100, 9946-9951. doi: 10.1073/pnas. 1334037100

Lee, D. Y., Lee, J., and Sugden, B. (2009). The unfolded protein response and autophagy: herpesviruses rule! J. Virol. 83, 1168-1172. doi: 10.1128/JVI. 01358-08

Lee, D. Y., and Sugden, B. (2008). The LMP1 oncogene of EBV activates PERK and the unfolded protein response to drive its own synthesis. Blood 111, 2280-2289. doi: 10.1182/blood-2007-07-100032

Lee, K., Tirasophon, W., Shen, X., Michalak, M., Prywes, R., Okada, T., et al. (2002). IRE1-mediated unconventional mRNA splicing and S2P-mediated ATF6 cleavage merge to regulate XBP1 in signaling the unfolded protein response. Genes Dev. 16, 452-466. doi: 10.1101/gad.964702

Liang, Q., Deng, H., Sun, C. W., Townes, T. M., and Zhu, F. (2011). Negative regulation of IRF7 activation by activating transcription factor 4 suggests a cross-regulation between the IFN responses and the cellular integrated stress responses. J. Immunol. 186, 1001-1010. doi: 10.4049/jimmunol.1002240

Liu, J. X., and Howell, S. H. (2010). bZIP28 and NF-Y transcription factors are activated by ER stress and assemble into a transcriptional complex to regulate stress response genes in Arabidopsis. Plant Cell 22, 782-796. doi: $10.1105 /$ tpc. 109.072173

Malhotra, J. D., and Kaufman, R. J. (2007). The endoplasmic reticulum and the unfolded protein response. Semin. Cell Dev. Biol. 18, 716-731. doi: 10.1016/j.semcdb.2007.09.003

Manno, C. S., Pierce, G. F., Arruda, V. R., Glader, B., Ragni, M., Rasko, J. J., et al. (2006). Successful transduction of liver in hemophilia by AAV-Factor IX and limitations imposed by the host immune response. Nat. Med. 12, 342-347. doi: $10.1038 / \mathrm{nm} 1358$

Marcinak, S. J., and Ron, D. (2010). The unfolded protein response in lung disease. Proc. Am. Thorac. Soc. 7, 356-362. doi: 10.1513/pats.201001-015AW

Markusic, D. M., Herzog, R. W., Aslanidi, G. V., Hoffman, B. E., Li, B., Li, M., et al. (2010). High-efficiency transduction and correction of murine hemophilia B using AAV2 vectors devoid of multiple surface-exposed tyrosines. Mol. Ther. 18, 2048-2056. doi: 10.1038/mt.2010.172

Markwell, M. A., Svennerholm, L., and Paulson, J. C. (1981). Specific gangliosides function as host cell receptors for Sendai virus. Proc. Natl. Acad. Sci. U.S.A. 78, 5406-5410. doi: 10.1073/pnas.78.9.5406

Martino, M. B., Jones, L., Brighton, B., Ehre, C., Abdulah, L., Davis, C. W., et al. (2013). The ER stress transducer IRElbeta is required for airway epithelial mucin production. Mucosal Immunol. 6, 639-654. doi: 10.1038/mi.2012.105

Masaki, I., Yonemitsu, Y., Komori, K., Ueno, H., Nakashima, Y., Nakagawa, K., et al. (2001). Recombinant Sendai virus-mediated gene transfer to vasculature: a new class of efficient gene transfer vector to the vascular system. FASEB J. 15, 1294-1296. doi: 10.1096/fj.00-0460fje

Mathews, M. B., and Shenk, T. (1991). Adenovirus virus-associated RNA and translation control. J. Virol. 65, 5657-5662.

McKenna, S. A., Kim, I., Liu, C. W., and Puglisi, J. D. (2006). Uncoupling of RNA binding and PKR kinase activation by viral inhibitor RNAs. J. Mol. Biol. 358, 1270-1285. doi: 10.1016/j.jmb.2006.03.003

Meusser, B., Hirsch, C., Jarosch, E., and Sommer, T. (2005). ERAD: the long road to destruction. Nat. Cell Biol. 7, 766-772. doi: 10.1038/ncb0805-766

Min, J., Shukla, H., Kozono, H., Bronson, S. K., Weissman, S. M., and Chaplin, D. D. (1995). A novel Creb family gene telomeric of HLA-DRA in the HLA complex. Genomics 30, 149-156. doi: 10.1006/geno.1995.9891

Misra, S. (2013). Human gene therapy: a brief overview of the genetic revolution. J. Assoc. Physicians India 61, 127-133.

Molina, S., Sanz, M. A., Madan, V., Ventoso, I., Castello, A., and Carrasco, L. (2007). Differential inhibition of cellular and Sindbis virus translation 
by brefeldin A. Virology 363, 430-436. doi: 10.1016/j.virol.2007. 02.001

Monahan, P. E., Lothrop, C. D., Sun, J., Hirsch, M. L., Kafri, T., Kantor, B., et al. (2010). Proteasome inhibitors enhance gene delivery by AAV virus vectors expressing large genomes in hemophilia mouse and dog models: a strategy for broad clinical application. Mol. Ther. 18, 1907-1916. doi: 10.1038/mt.2010.170

Moriuchi, S., Wolfe, D., Tamura, M., Yoshimine, T., Miura, F., Cohen, J. B., et al. (2002). Double suicide gene therapy using a replication defective herpes simplex virus vector reveals reciprocal interference in a malignant glioma model. Gene Ther. 9, 584-591. doi: 10.1038/sj.gt.3301693

Mulvey, M., Arias, C., and Mohr, I. (2006). Resistance of mRNA translation to acute endoplasmic reticulum stress-inducing agents in herpes simplex virus type 1infected cells requires multiple virus-encoded functions. J. Virol. 80, 7354-7363. doi: 10.1128/JVI.00479-06

Mulvey, M., Arias, C., and Mohr, I. (2007). Maintenance of endoplasmic reticulum (ER) homeostasis in herpes simplex virus type 1-infected cells through the association of a viral glycoprotein with PERK, a cellular ER stress sensor. J. Virol. 81, 3377-3390. doi: 10.1128/JVI.02191-06

Mulvey, M., Poppers, J., Sternberg, D., and Mohr, I. (2003). Regulation of eIF2alpha phosphorylation by different functions that act during discrete phases in the herpes simplex virus type 1 life cycle. J. Virol. 77, 10917-10928. doi: 10.1128/JVI.77.20.10917-10928.2003

Nagasaki, Y., Matsubara, Y., Takano, H., Fujii, K., Senoo, M., Akanuma, J., et al. (1999). Reversal of hypopigmentation in phenylketonuria mice by adenovirusmediated gene transfer. Pediatr. Res. 45, 465-473. doi: 10.1203/00006450199904010-00003

Naidoo, N. (2009). ER and aging-Protein folding and the ER stress response. Ageing Res. Rev. 8, 150-159. doi: 10.1016/j.arr.2009.03.001

Nanua, S., and Yoshimura, F. K. (2004). Mink epithelial cell killing by pathogenic murine leukemia viruses involves endoplasmic reticulum stress. J. Virol. 78, 12071-12074. doi: 10.1128/JVI.78.21.12071-12074.2004

Nathwani, A. C., Tuddenham, E. G., Rangarajan, S., Rosales, C., McIntosh, J., Linch, D. C., et al. (2011). Adenovirus-associated virus vector-mediated gene transfer in hemophilia B. N. Engl. J. Med. 365, 2357-2365. doi: 10.1056/NEJMoal108046

Netherton, C. L., Parsley, J. C., and Wileman, T. (2004). African swine fever virus inhibits induction of the stress-induced proapoptotic transcription factor CHOP/GADD153. J. Virol. 78, 10825-10828. doi: 10.1128/JVI.78.19.1082510828.2004

Niranjan, A., Moriuchi, S., Lunsford, L. D., Kondziolka, D., Flickinger, J. C., Fellows, W., et al. (2000). Effective treatment of experimental glioblastoma by HSV vector-mediated TNF alpha and HSV-tk gene transfer in combination with radiosurgery and ganciclovir administration. Mol. Ther. 2, 114-120. doi: $10.1006 /$ mthe.2000.0101

Niranjan, A., Wolfe, D., Tamura, M., Soares, M. K., Krisky, D. M., Lunsford, L. D., et al. (2003). Treatment of rat gliosarcoma brain tumors by HSV-based multigene therapy combined with radiosurgery. Mol. Ther. 8, 530-542. doi: 10.1016/S1525-0016(03)00232-6

Norgren, R. B. Jr., and Lehman, M. N. (1998). Herpes simplex virus as a transneuronal tracer. Neurosci. Biobehav. Rev. 22, 695-708. doi: 10.1016/S01497634(98)00008-6

Novoa, I., Zhang, Y., Zeng, H., Jungreis, R., Harding, H. P., and Ron, D. (2003). Stress-induced gene expression requires programmed recovery from translational repression. EMBO J. 22, 1180-1187. doi: 10.1093/emboj/cdg112

Orvedahl, A., Macpherson, S., Sumpter, R. Jr., Talloczy, Z., Zou, Z., and Levine, B. (2010). Autophagy protects against Sindbis virus infection of the central nervous system. Cell Host Microbe 7, 115-127. doi: 10.1016/j.chom.2010.01.007

Pahl, H. L., and Baeuerle, P. A. (1995). A novel signal transduction pathway from the endoplasmic reticulum to the nucleus is mediated by transcription factor NF-kappa B. EMBO J. 14, 2580-2588.

Papadopoulos, M. C., Giffard, R. G., and Bell, B. A. (2000). Principles of gene therapy: potential applications in the treatment of cerebral ischaemia. $\mathrm{Br}$. J. Neurosurg. 14, 407-414. doi: 10.1080/02688690050175184

Paradkar, P. N., Ooi, E. E., Hanson, B. J., Gubler, D. J., and Vasudevan, S. G. (2011). Unfolded protein response (UPR) gene expression during antibodydependent enhanced infection of cultured monocytes correlates with dengue disease severity. Biosci. Rep. 31, 221-230. doi: 10.1042/BSR20100078

Parikh, B. A., Tortora, A., Li, X. P., and Tumer, N. E. (2008). Ricin inhibits activation of the unfolded protein response by preventing splicing of the HAC1 mRNA. J. Biol. Chem. 283, 6145-6153. doi: 10.1074/jbc.M707981200
Pena, J., and Harris, E. (2011). Dengue virus modulates the unfolded protein response in a time-dependent manner. J. Biol. Chem. 286, 14226-14236. doi: 10.1074/jbc.M111.222703

Porteus, M. H., Connelly, J. P., and Pruett, S. M. (2006). A look to future directions in gene therapy research for monogenic diseases. PLoS Genet. 2:e133. doi: 10.1371/journal.pgen.0020133

Post, D. E., Fulci, G., Chiocca, E. A., and Van Meir, E. G. (2004). Replicative oncolytic herpes simplex viruses in combination cancer therapies. Curr. Gene Ther. 4, 41-51. doi: 10.2174/1566523044577988

Qiao, C., Zhang, W., Yuan, Z., Shin, J. H., Li, J., Jayandharan, G. R., et al. (2010). Adeno-associated virus serotype 6 capsid tyrosine-to-phenylalanine mutations improve gene transfer to skeletal muscle. Hum. Gene Ther. 21, 1343-1348. doi: 10.1089/hum.2010.003

Rafi, M. A., Rao, H. Z., Luzi, P., Curtis, M. T., and Wenger, D. A. (2012). Extended normal life after AAVrh10-mediated gene therapy in the mouse model of Krabbe disease. Mol. Ther. 20, 2031-2042. doi: 10.1038/mt.2012.153

Rajkumar, S. V., Richardson, P. G., Hideshima, T., and Anderson, K. C. (2005). Proteasome inhibition as a novel therapeutic target in human cancer. J. Clin. Oncol. 23, 630-639. doi: 10.1200/JCO.2005.11.030

Rao, R. V., and Bredesen, D. E. (2004). Misfolded proteins, endoplasmic reticulum stress and neurodegeneration. Curr. Opin. Cell Biol. 16, 653-662. doi: 10.1016/j.ceb.2004.09.012

Rathore, A. P., Ng, M. L., and Vasudevan, S. G. (2013). Differential unfolded protein response during Chikungunya and Sindbis virus infection: CHIKV nsP4 suppresses eIF2alpha phosphorylation. Virol. J. 10, 36. doi: 10.1186/1743-422X10-36

Raven, J. F., Baltzis, D., Wang, S., Mounir, Z., Papadakis, A. I., Gao, H. Q., et al. (2008). PKR and PKR-like endoplasmic reticulum kinase induce the proteasome-dependent degradation of cyclin D1 via a mechanism requiring eukaryotic initiation factor 2alpha phosphorylation. J. Biol. Chem. 283, 3097-3108. doi: 10.1074/jbc.M709677200

Roks, A. J., Pinto, Y. M., Paul, M., Pries, F., Stula, M., Eschenhagen, T., et al. (1997). Vectors based on Semliki Forest virus for rapid and efficient gene transfer into non-endothelial cardiovascular cells: comparison to adenovirus. Cardiovasc. Res. 35, 498-504. doi: 10.1016/S0008-6363(97)00173-9

Ron, D., and Walter, P. (2007). Signal integration in the endoplasmic reticulum unfolded protein response. Nat. Rev. Mol. Cell Biol. 8, 519-529. doi: 10.1038/nrm2199

Ryan, D. A., and Federoff, H. J. (2009). Immune responses to herpesviral vectors. Hum. Gene Ther. 20, 434-441. doi: 10.1089/hum.2009.019

Schroder, M., and Kaufman, R. J. (2005). The mammalian unfolded protein response. Annu Rev. Biochem. 74, 739-789. doi: 10.1146/annurev.biochem.73.011303.074134

Sen, D., Balakrishnan, B., Gabriel, N., Agrawal, P., Roshini, V., Samuel, R., et al. (2013a). Improved adeno-associated virus (AAV) serotype 1 and 5 vectors for gene therapy. Sci. Rep. 3, 1832. doi: 10.1038/srep01832

Sen, D., Gadkari, R. A., Sudha, G., Gabriel, N., Kumar, Y. S., Selot, R., et al. (2013b). Targeted modifications in adeno-associated virus serotype 8 capsid improves its hepatic gene transfer efficiency in vivo. Hum. Gene Ther. Methods 24, 104-116. doi: 10.1089/hgtb.2012.195

Seubert, C. M., Stritzker, J., Hess, M., Donat, U., Sturm, J. B., Chen, N., et al. (2011). Enhanced tumor therapy using vaccinia virus strain GLV1 h68 in combination with a beta-galactosidase-activatable prodrug secoanalog of duocarmycin SA. Cancer Gene Ther. 18, 42-52. doi: 10.1038/cgt. 2010.49

Shen, X., Ellis, R. E., Lee, K., Liu, C. Y., Yang, K., Solomon, A., et al. (2001). Complementary signaling pathways regulate the unfolded protein response and are required for C. elegans development. Cell 107, 893-903. doi: 10.1016/S00928674(01)00612-2

Shen, Y., and Nemunaitis, J. (2005). Fighting cancer with vaccinia virus: teaching new tricks to an old dog. Mol. Ther. 11, 180-195. doi: 10.1016/j.ymthe.2004.10.015

Shi, J., and Luo, H. (2012). Interplay between the cellular autophagy machinery and positive-stranded RNA viruses. Acta Biochim. Biophys. Sin. (Shanghai) 44, 375-384. doi: 10.1093/abbs/gms010

Shikova, E., Lin, Y. C., Saha, K., Brooks, B. R., and Wong, P. K. (1993). Correlation of specific virus-astrocyte interactions and cytopathic effects induced by tsl, a neurovirulent mutant of Moloney murine leukemia virus. J. Virol. 67, 1137-1147. 
Shiotani, A., Fukumura, M., Maeda, M., Hou, X., Inoue, M., Kanamori, T., et al. (2001). Skeletal muscle regeneration after insulin-like growth factor I gene transfer by recombinant Sendai virus vector. Gene Ther. 8, 1043-1050. doi: 10.1038/sj.gt.3301486

Simonelli, F., Maguire, A. M., Testa, F., Pierce, E. A., Mingozzi, F., Bennicelli, J. L., et al. (2010). Gene therapy for Leber's congenital amaurosis is safe and effective through 1.5 years after vector administration. Mol. Ther. 18, 643-650. doi: 10.1038/mt.2009.277

Soderlund, H., Pettersson, U., Vennstrom, B., Philipson, L., and Mathews, M. B. (1976). A new species of virus-coded low molecular weight RNA from cells infected with adenovirus type 2. Cell 7, 585-593. doi: 10.1016/00928674(76)90209-9

Sood, R., Porter, A. C., Ma, K., Quilliam, L. A., and Wek, R. C. (2000). Pancreatic eukaryotic initiation factor-2alpha kinase (PEK) homologues in humans, Drosophila melanogaster and Caenorhabditis elegans that mediate translational control in response to endoplasmic reticulum stress. Biochem. J. 346(Pt 2), 281-293. doi: 10.1042/0264-6021:3460281

Spurgeon, M. E., and Ornelles, D. A. (2009). The adenovirus E1B 55-kilodalton and E4 open reading frame 6 proteins limit phosphorylation of eIF2alpha during the late phase of infection. J. Virol. 83, 9970-9982. doi: 10.1128/JVI.01113-09

Stahl, S., Burkhart, J. M., Hinte, F., Tirosh, B., Mohr, H., Zahedi, R. P., et al. (2013). Cytomegalovirus downregulates IRE1 to repress the unfolded protein response. PLoS Pathog. 9:e1003544. doi: 10.1371/journal.ppat.1003544

Stein, C. S., Martins, I., and Davidson, B. L. (2000). Long-term reversal of hypercholesterolemia in low density lipoprotein receptor (LDLR)-deficient mice by adenovirus-mediated LDLR gene transfer combined with CD154 blockade. J. Gene Med. 2, 41-51. doi: 10.1002/(SICI)1521-2254(200001/02)2:1<41::AIDJGM79>3.0.CO;2-P

Stevens, F. J., and Argon, Y. (1999). Protein folding in the ER. Semin. Cell Dev. Biol. 10, 443-454. doi: 10.1006/scdb.1999.0315

Svensson, C., and Akusjarvi, G. (1984). Adenovirus VA RNAI: a positive regulator of mRNA translation. Mol. Cell. Biol. 4, 736-742.

Tabas, I., and Ron, D. (2011). Integrating the mechanisms of apoptosis induced by endoplasmic reticulum stress. Nat. Cell Biol. 13, 184-190. doi: 10.1038/ncb03 11-184

Talloczy, Z., Virgin, H. W. T., and Levine, B. (2006). PKR-dependent autophagic degradation of herpes simplex virus type 1. Autophagy 2, 24-29.

Tam, A. B., Mercado, E. L., Hoffmann, A., and Niwa, M. (2012). ER stress activates NF-kappaB by integrating functions of basal IKK activity, IRE1 and PERK. PLoS ONE 7:e45078. doi: 10.1371/journal.pone.0045078

Tang, Y., Cummins, J., Huard, J., and Wang, B. (2010). AAV-directed muscular dystrophy gene therapy. Expert Opin. Biol. Ther. 10, 395-408. doi: $10.1517 / 14712591003604690$

Tardif, K. D., Mori, K., Kaufman, R. J., and Siddiqui, A. (2004). Hepatitis C virus suppresses the IRE1-XBP1 pathway of the unfolded protein response. J. Biol. Chem. 279, 17158-17164. doi: 10.1074/jbc.M312144200

Taylor, G. M., Raghuwanshi, S. K., Rowe, D. T., Wadowsky, R. M., and Rosendorff, A. (2011). Endoplasmic reticulum stress causes EBV lytic replication. Blood 118, 5528-5539. doi: 10.1182/blood-2011-04-347112

Taylor, J. M., Quilty, D., Banadyga, L., and Barry, M. (2006). The vaccinia virus protein F1L interacts with Bim and inhibits activation of the pro-apoptotic protein Bax. J. Biol. Chem. 281, 39728-39739. doi: 10.1074/jbc.M607465200

Theriault, J. R., Palmer, H. J., and Pittman, D. D. (2011). Inhibition of the Unfolded Protein Response by metformin in renal proximal tubular epithelial cells. Biochem. Biophys. Res. Commun. 409, 500-505. doi: 10.1016/j.bbrc.2011.05.034

Thimmappaya, B., Weinberger, C., Schneider, R. J., and Shenk, T. (1982). Adenovirus VAI RNA is required for efficient translation of viral mRNAs at late times after infection. Cell 31, 543-551. doi: 10.1016/0092-8674(82) 90310-5

Tiede, L. M., Cook, E. A., Morsey, B., and Fox, H. S. (2011). Oxygen matters: tissue culture oxygen levels affect mitochondrial function and structure as well as responses to HIV viroproteins. Cell Death Dis. 2, e246. doi: $10.1038 /$ cddis. 2011.128

Tirasophon, W., Welihinda, A. A., and Kaufman, R. J. (1998). A stress response pathway from the endoplasmic reticulum to the nucleus requires a novel bifunctional protein kinase/endoribonuclease (Irelp) in mammalian cells. Genes Dev. 12, 1812-1824. doi: 10.1101/gad.12.12.1812

Trobridge, G. D. (2009). Foamy virus vectors for gene transfer. Expert Opin. Biol. Ther. 9, 1427-1436. doi: 10.1517/14712590903246388
Trujillo-Alonso, V., Maruri-Avidal, L., Arias, C. F., and Lopez, S. (2011). Rotavirus infection induces the unfolded protein response of the cell and controls it through the nonstructural protein NSP3. J. Virol. 85, 12594-12604. doi: 10.1128/JVI.05620-11

Urano, F., Wang, X., Bertolotti, A., Zhang, Y., Chung, P., Harding, H. P., et al. (2000). Coupling of stress in the ER to activation of JNK protein kinases by transmembrane protein kinase IRE1. Science 287, 664-666. doi: 10.1126/science.287.5453.664

Versteeg, G. A., Van De Nes, P. S., Bredenbeek, P. J., and Spaan, W. J. (2007). The coronavirus spike protein induces endoplasmic reticulum stress and upregulation of intracellular chemokine mRNA concentrations. J. Virol. 81, 10981-10990. doi: 10.1128/JVI.01033-07

Wang, G. P., Levine, B. L., Binder, G. K., Berry, C. C., Malani, N., McGarrity, G. et al. (2009a). Analysis of lentiviral vector integration in HIV+ study subjects receiving autologous infusions of gene modified CD4+ T cells. Mol. Ther. 17, 844-850. doi: 10.1038/mt.2009.16

Wang, J., Fan, Q., Satoh, T., Arii, J., Lanier, L. L., Spear, P. G., et al. (2009b). Binding of herpes simplex virus glycoprotein $\mathrm{B}(\mathrm{gB})$ to paired immunoglobulin-like type 2 receptor alpha depends on specific sialylated O-linked glycans on gB. J. Virol. 83, 13042-13045. doi: 10.1128/JVI.00792-09

Wright, J. F. (2009). Transient transfection methods for clinical adenoassociated viral vector production. Hum. Gene Ther. 20, 698-706. doi: 10.1089/hum.2009.064

Wu, J., Rutkowski, D. T., Dubois, M., Swathirajan, J., Saunders, T., Wang, J., et al. (2007). ATF6alpha optimizes long-term endoplasmic reticulum function to protect cells from chronic stress. Dev. Cell 13, 351-364. doi: 10.1016/j.devcel.2007.07.005

Xu, C., Bailly-Maitre, B., and Reed, J. C. (2005). Endoplasmic reticulum stress: cell life and death decisions. J. Clin. Invest. 115, 2656-2664. doi: 10.1172/JCI 26373

Yamada, M., Lewis, J. A., and Grodzicker, T. (1985). Overproduction of the protein product of a nonselected foreign gene carried by an adenovirus vector. Proc. Natl. Acad. Sci. U.S.A. 82, 3567-3571. doi: 10.1073/pnas.82. 11.3567

Yamamoto, K., Sato, T., Matsui, T., Sato, M., Okada, T., Yoshida, H., et al. (2007). Transcriptional induction of mammalian ER quality control proteins is mediated by single or combined action of ATF6alpha and XBP1. Dev. Cell 13, 365-376. doi: 10.1016/j.devcel.2007.07.018

Yamashita, A., Yonemitsu, Y., Okano, S., Nakagawa, K., Nakashima, Y., Irisa, T., et al. (2002). Fibroblast growth factor-2 determines severity of joint disease in adjuvant-induced arthritis in rats. J. Immunol. 168, 450-457. doi: 10.4049/jimmunol.168.1.450

Yao, F., and Schaffer, P. A. (1994). Physical interaction between the herpes simplex virus type 1 immediate-early regulatory proteins ICP0 and ICP4. J. Virol. 68, 8158-8168.

Ye, C., Dickman, M. B., Whitham, S. A., Payton, M., and Verchot, J. (2011). The unfolded protein response is triggered by a plant viral movement protein. Plant Physiol. 156, 741-755. doi: 10.1104/pp.111.174110

Yonemitsu, Y., Kitson, C., Ferrari, S., Farley, R., Griesenbach, U., Judd, D., et al. (2000). Efficient gene transfer to airway epithelium using recombinant Sendai virus. Nat. Biotechnol. 18, 970-973. doi: 10.1038/79463

Yorimitsu, T., Nair, U., Yang, Z., and Klionsky, D. J. (2006). Endoplasmic reticulum stress triggers autophagy. J. Biol. Chem. 281, 30299-30304. doi: 10.1074/jbc.M607007200

Yoshida, H., Matsui, T., Yamamoto, A., Okada, T., and Mori, K. (2001). XBP1 mRNA is induced by ATF6 and spliced by IRE1 in response to ER stress to produce a highly active transcription factor. Cell 107, 881-891. doi: 10.1016/S00928674(01)00611-0

Yu, Y. A., Shabahang, S., Timiryasova, T. M., Zhang, Q., Beltz, R., Gentschev, I., et al. (2004). Visualization of tumors and metastases in live animals with bacteria and vaccinia virus encoding light-emitting proteins. Nat. Biotechnol. 22, 313-320. doi: $10.1038 /$ nbt937

Yu, Z., Li, S., Brader, P., Chen, N., Yu, Y. A., Zhang, Q., et al. (2009). Oncolytic vaccinia therapy of squamous cell carcinoma. Mol. Cancer 8:45. doi: 10.1186/14764598-8-45

Zhang, J., Asselin-Paturel, C., Bex, F., Bernard, J., Chehimi, J., Willems, F., et al. (1997). Cloning of human IL-12 p40 and p35 DNA into the Semliki Forest virus vector: expression of IL-12 in human tumor cells. Gene Ther. 4, 367-374. doi: 10.1038/sj.gt.3300409 
Zhang, K., and Kaufman, R. J. (2006). The unfolded protein response: a stress signaling pathway critical for health and disease. Neurology 66, S102-S109. doi: 10.1212/01.wnl.0000192306.98198.ec

Zhang, L., and Wang, A. (2012). Virus-induced ER stress and the unfolded protein response. Front. Plant Sci. 3:293. doi: 10.3389/fpls.2012.00293

Zhang, W. W. (1999). Development and application of adenoviral vectors for gene therapy of cancer. Cancer Gene Ther. 6, 113-138. doi: 10.1038/sj.cgt.7700024

Ziegler, R. J., Yew, N. S., Li, C., Cherry, M., Berthelette, P., Romanczuk, H., et al. (1999). Correction of enzymatic and lysosomal storage defects in Fabry mice by adenovirus-mediated gene transfer. Hum. Gene Ther. 10, 1667-1682. doi: 10.1089/10430349950017671

Zincarelli, C., Soltys, S., Rengo, G., and Rabinowitz, J. E. (2008). Analysis of AAV serotypes 1-9 mediated gene expression and tropism in mice after systemic injection. Mol. Ther. 16, 1073-1080. doi: 10.1038/mt.2008.76

Zingone, A., Hiraiwa, H., Pan, C. J., Lin, B., Chen, H., Ward, J. M., et al. (2000). Correction of glycogen storage disease type 1a in a mouse model by gene therapy. J. Biol. Chem. 275, 828-832. doi: 10.1074/jbc.275. 2.828

Zinszner, H., Kuroda, M., Wang, X., Batchvarova, N., Lightfoot, R. T., Remotti, H., et al. (1998). CHOP is implicated in programmed cell death in response to impaired function of the endoplasmic reticulum. Genes Dev. 12, 982-995. doi: $10.1101 /$ gad.12.7.982
Zuckerman, J. B., Robinson, C. B., McCoy, K. S., Shell, R., Sferra, T. J., Chirmule, N., et al. (1999). A phase I study of adenovirus-mediated transfer of the human cystic fibrosis transmembrane conductance regulator gene to a lung segment of individuals with cystic fibrosis. Hum. Gene Ther. 10, 2973-2985. doi: $10.1089 / 10430349950016384$

Conflict of Interest Statement: The authors declare that the research was conducted in the absence of any commercial or financial relationships that could be construed as a potential conflict of interest.

Received: 24 March 2014; accepted: 07 May 2014; published online: 26 May 2014.

Citation: Sen D, Balakrishnan B and Jayandharan GR (2014) Cellular unfolded protein response against viruses used in gene therapy. Front. Microbiol. 5:250. doi: $10.3389 /$ fmicb.2014.00250

This article was submitted to Virology, a section of the journal Frontiers in Microbiology.

Copyright (C) 2014 Sen, Balakrishnan and Jayandharan. This is an open-access article distributed under the terms of the Creative Commons Attribution License (CC BY). The use, distribution or reproduction in other forums is permitted, provided the original author(s) or licensor are credited and that the original publication in this journal is cited, in accordance with accepted academic practice. No use, distribution or reproduction is permitted which does not comply with these terms. 